\title{
Role of Basal ABA in Plant Growth and Development
}

\author{
Benjamin P. Brookbank ${ }^{1,+}$, Jasmin Patel ${ }^{1,2,+}$, Sonia Gazzarrini ${ }^{1,2, *}$ and Eiji Nambara ${ }^{1, *}$ \\ 1 Department of Cells and Systems Biology, University of Toronto, Toronto, ON M3S 3G5, Canada; \\ ben.brookbank@mail.utoronto.ca (B.P.B.); jas.patel@mail.utoronto.ca (J.P.) \\ 2 Department of Biological Sciences, University of Toronto Scarborough, Toronto, ON M1C 1A4, Canada \\ * Correspondence: sonia.gazzarrini@utoronto.ca (S.G.); eiji.nambara@utoronto.ca (E.N.) \\ + These authors contributed equally to this work.
}

Citation: Brookbank, B.P.; Patel, J.; Gazzarrini, S.; Nambara, E. Role of Basal ABA in Plant Growth and Development. Genes 2021, 12, 1936. https://doi.org/10.3390/ genes12121936

Academic Editor: Benoît Lacombe

Received: 8 November 2021

Accepted: 28 November 2021

Published: 30 November 2021

Publisher's Note: MDPI stays neutral with regard to jurisdictional claims in published maps and institutional affiliations.

\begin{abstract}
Abscisic acid (ABA) regulates various aspects of plant physiology, including promoting seed dormancy and adaptive responses to abiotic and biotic stresses. In addition, ABA plays an im-portant role in growth and development under non-stressed conditions. This review summarizes phenotypes of ABA biosynthesis and signaling mutants to clarify the roles of basal ABA in growth and development. The promotive and inhibitive actions of $\mathrm{ABA}$ in growth are characterized by stunted and enhanced growth of ABA-deficient and insensitive mutants, respectively. Growth regulation by $\mathrm{ABA}$ is both promotive and inhibitive, depending on the context, such as concentrations, tissues, and environmental conditions. Basal ABA regulates local growth including hyponastic growth, skotomorphogenesis and lateral root growth. At the cellular level, basal ABA is essential for proper chloroplast biogenesis, central metabolism, and expression of cell-cycle genes. Basal ABA also regulates epidermis development in the shoot, by inhibiting stomatal development, and deposition of hydrophobic polymers like a cuticular wax layer covering the leaf surface. In the root, basal ABA is involved in xylem differentiation and suberization of the endodermis. Hormone crosstalk plays key roles in growth and developmental processes regulated by ABA. Phenotypes of ABA-deficient and insensitive mutants indicate prominent functions of basal $\mathrm{ABA}$ in plant growth and development.
\end{abstract}

Keywords: ABA; chloroplast biogenesis; hyponastic growth; skotomorphogenesis; stomata; cutin; wax; suberin; xylem; hormone crosstalk; ethylene

\section{Introduction}

The sesquiterpenoid hormone abscisic acid (ABA) regulates numerous plant processes, including growth and development [1]. ABA plays a well-characterized role in promoting seed and bud dormancy, as well as regulating stress responses in various plant species [2-4]. During dormancy establishment and following stress, ABA levels sharply increase leading to inhibition of germination and growth arrest to mount a stress response. However, in well-watered plants, basal amounts of $\mathrm{ABA}$ are required to promote growth and development of various organs and tissues [5,6]. Here, we summarize the phenotypes of ABA biosynthesis and signaling mutants and highlight the role of basal ABA in plant growth and development as well as its interaction with other hormones, with a focus on genetic evidence.

\subsection{Everything in Moderation: ABA Deficiency and over-Accumulation}

ABA-deficient mutants are useful for elucidating its roles in plant growth and development. Phenotypes of ABA-deficient mutants depend on the severity of ABA deficiency and the types of enzymes mutated. ABA is synthesized via oxidative cleavage of 9-cisepoxycarotenoids derived from $\beta$-carotene [7]. Thus, mutants defective in $\beta$-carotenoid biosynthesis and its downstream pathway show ABA deficiency. Due to pleiotropic phenotypes of carotenoid deficiency, mutants defective in zeaxanthin epoxidase (ZEP) or more downstream enzymes are used for ABA-deficient mutants in research. ZEP catalyzes a 
two-step epoxidation of zeaxanthin to violaxanthin. The zep mutants have been isolated from various plants, including Arabidopsis aba1, tomato high-pigment 3 ( $h p 3$ ), and rice osaba1 [8-10]. The zep mutants over-accumulate zeaxanthin and show decreased levels of epoxycarotenoids and downstream metabolites, including ABA $[8,10]$. Zeaxanthin and epoxycarotenoids play an important role in quenching reactive oxygen species (ROS), byproducts of photosynthesis, to protect photosynthesis proteins from photo-oxidative damage [11]. Thus, phenotypes of zep mutants are caused by both ABA deficiency and altered xanthophyll contents. On the other hand, mutants of 9-cis-epoxycarotenoid dioxygenase (NCED), xanthoxin dehydrogenase (ABA2) and abscisic aldehyde oxidase (AAO3) are thought to be the specific ABA-deficient mutants. Severity of ABA deficiency is often associated with the number of gene family members. The Arabidopsis $A t A B A 2$, rice OsABA2 and pea $P_{S} A B A 2 / W I L T Y$ are single-gene coded in the genome, therefore mutations in these genes show severe ABA deficiency $[12,13]$. NCEDs are encoded by multigene families, so the severity of ABA deficiency largely depends on expression divergence among family members. The well characterized nced mutants include maize op 14, Arabidopsis nced mutants, tomato notabilis (not) [7]. Also, inhibitors to block the NCED enzyme activities, such as nordihydroguaiaretic acid (NDGA), abamine SG and hydroxamic acid inhibitor D4, have been used to chemically induce ABA deficiency [14-16]. AAO3 catalyzes the last step of ABA biosynthesis. Arabidopsis aao3 and tomato sitiens (sit) have been well characterized for various physiological responses [7]. In Arabidopsis, $A A O 3$ seems to be the only aldehyde oxidase $(\mathrm{AO})$ encoding the physiological abscisic aldehyde oxidase, but other three AOs convert abscisic aldehyde to ABA at a basal level in the aao3 mutant due to the promiscuity of substrate recognition [17]. Thus, the severity of ABA deficiency of the aao3 mutant is less pronounced compared to the $a b a 2$ mutant. $\mathrm{AAO} 3$ is an $\mathrm{AO}$ that requires a molybdenum cofactor (MoCo), thus mutants having a defect in MoCo biosynthesis show ABA deficiency. In plants, nitrate reductases $(\mathrm{NR})$, xanthine dehydrogenases $(\mathrm{XDH})$, peroxisomal sulfite oxidases ( $\mathrm{SO}$ ) and $\mathrm{AOs}$ are well characterized as MoCo containing enzymes in plants [18]. MoCo sulfurase encoded by ABA3 in Arabidopsis catalyzes the maturation step of MoCo biosynthesis required for $\mathrm{AO}$ and $\mathrm{XDH}$ function. Thus, Arabidopsis $a b a 3$ and tomato flacca (fla) mutants have defects in AO and XDH activities $[19,20]$. Therefore, the $a b a 3$ mutant shows both ABA-dependent and independent phenotypes [21]. On the other hand, barley Az34 mutant show defects in NR, XDH, as well as AO indicating that the genetic defect of this mutant is upstream of $\mathrm{ABA} 3$, causing more pleiotropic phenotypes than the aba3 mutant [22].

ABA is inactivated by oxidation and sugar conjugation [7]. CYP707As, a subfamily of $\mathrm{P} 450$ monooxygenases, catalyzes ABA 8'-hydroxylation responsible for oxidative catabolism of ABA. ABA glycosylation inactivates $\mathrm{ABA}$, but ABA glucose ester is stored and can be released by ABA $\beta$-glucosidase (BG). The cyp707a mutants contain higher ABA levels, which decrease slower when dehydrated plants are watered or dry seeds are imbibed [23-25]. Selective inhibitors for CYP707As have been developed by utilizing P450 inhibitors or ABA analogs as lead compounds [26,27]. These inhibitors are useful to maintain endogenous $\mathrm{ABA}$ at the high levels, although the right choice of concentrations is required to minimize off-target effects [28].

\subsection{Perception Is Key: ABA Insensitivity and Hypersensitivity}

The ABA signaling pathway requires three types of proteins as core components: PYR/PYL/RCAR receptors, group A protein phosphatase 2C (PP2C) and Sucrose NonFermenting 1-Related Protein Kinase 2 (SnRK2), [1]. PYR/PYL/RCAR receptors inhibit the phosphatase activity of PP2Cs in the presence of ABA [29,30]. Inhibition of PP2C, negative regulators of ABA signaling, derepresses SnRK2 to induce the downstream events [31]. Mutants of these core signaling genes are thought to be specific ABA signaling mutants $[32,33]$. In addition, transcription factors (TFs) identified from forward genetic analysis, such as ABA-INSENSITIVE3 (ABI3), ABI4 and ABI5 are important downstream regulators of the core signaling pathway $[1,34]$. Genes encoding the core signaling proteins belong to multi- 
gene families. For example, the Arabidopsis genome encodes 14 ABA receptor genes, while the rice genome contains 13 ABA receptor genes. Therefore, phenotypes of ABA receptor mutants are often visible only when higher order mutants are constructed [30,35-37]. Group A PP2C and SnRK2 form smaller gene families, therefore single mutants often show ABA-specific phenotypes. Six out of nine Group A PP2Cs are characterized as negative regulators of ABA signaling in Arabidopsis [38]. Loss-of-function mutants for ABA-INSENSITIVE1 (ABI1) and ABI2 are hypersensitive to ABA [39]. Mutants defective in ABA HYPERSENSITIVE GERMINATION 1 (AHG1) and AHG3 show a pronounced ABA hypersensitive phenotype during seed germination [40]. Mutations in the catalytic domain of PP2C, such as abi1-1, abi2-1 and hab1 ${ }^{G 246 D}$ confer dominant ABA-insensitive phenotypes [41]. Subclass III SnRK2 kinases are positive regulators of ABA signaling. Five out of 10 Arabidopsis SnRK2s are activated by ABA in a short period of time [42]. In particular, SnRK2.2/SRK2D, SnRK2.3/SRK2I and SnRK2.6/SRK2E/OST1 are primarily responsible for ABA signaling [38]. Antagonists and agonists against ABA receptors have been reported, which are also useful to induce ABA related phenotypes in plant species that are difficult to conduct genetic analysis [27,43,44].

\section{Role of ABA in Plant Growth}

ABA-mediated growth regulation involves crosstalk with other hormones and nutritional signaling, to regulate various aspects of cellular growth, including cell division, enlargement, differentiation, and central metabolism. Our understanding of how ABA regulates cellular growth is still fragmental. In rice, low concentrations of ABA are shown to upregulate a wide array of cell cycle related genes, including Cyclin-dependent kinases (CDKs) and cyclins (CYCs), in addition to auxin-related biosynthesis, transport, and signaling genes [45]. ABA regulation of cell cycle is in part explained by crosstalk with auxin and cytokinins $(\mathrm{CK})$, both of which are involved in cell cycle regulation $[46,47]$. ABA has been shown to promote CK signaling via ABI4 [48]. ABI4 binds to the promoter of type-A ARRs and supresses their transcription. Type-A ARRs serve as negative feedback regulators of CK signaling. Furthermore, type-A ARRs are upregulated in ABA-deficient mutants. CKs critically regulate cell division by promoting progression through key cell cycle checkpoints. CK application induces the expression of CDKs and CYCD proteins involved in both G1/S and G2/M phase transitions [49-52]. Cell elongation involves several mechanisms and is correlated with endoreduplication [53]. Endoreduplication occurs when cells enter an endocyclic phase. The endocycle is an alternative type of cell cycle where mitosis is skipped, resulting in repeated DNA replications within one nucleus (reviewed in [54]).

ABA is recognized as a growth inhibitor. This view is justified based on two lines of evidence: (i) high concentrations of exogenously applied ABA result in growth arrest [55] and (ii) endogenous ABA accumulates under a variety of stress conditions, concomitant with a reduction of growth in the stressed plant. This evidence ties in neatly with the identity of ABA as a stress hormone; since plants must balance growth programs against stress responses, it follows that ABA signaling should tip the scale in favour of allocating resources to cope with adverse environments at the expense of growth. However, the mode of ABA-mediated growth regulation varies depending on concentrations, timing, and tissues, showing both positive and negative effects on growth [5]. Context-dependent positive and negative growth regulation is known for other hormones, such as ethylene, $\mathrm{CK}$ and auxin [56-58]. This coincides with the prominent role of hormone crosstalk in ABA-mediated growth. We will summarize ABA-mediated growth regulation with an emphasis on the phenotypes of ABA-deficient and insensitive mutants (see also Figure 1 and Table 1). 


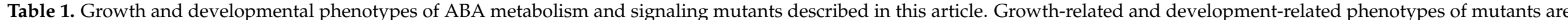
highlighted in green and yellow, respectively.

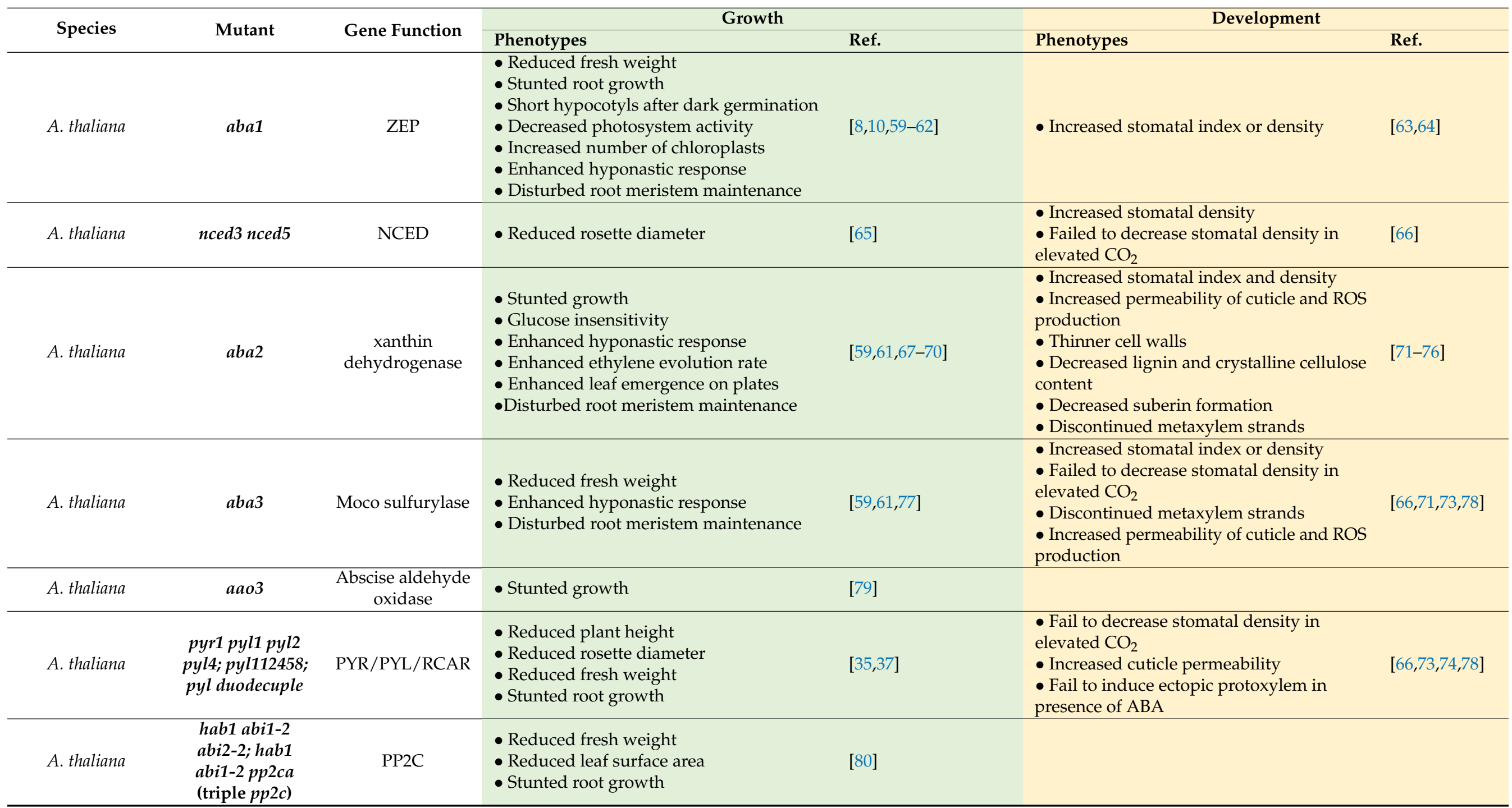


Table 1. Cont.

\begin{tabular}{|c|c|c|c|c|c|c|}
\hline \multirow{2}{*}{ Species } & \multirow{2}{*}{ Mutant } & \multirow{2}{*}{ Gene Function } & \multicolumn{2}{|l|}{ Growth } & \multicolumn{2}{|l|}{ Development } \\
\hline & & & Phenotypes & Ref. & Phenotypes & Ref. \\
\hline A. thaliana & $\begin{array}{l}\text { snrk2.2/2.3/2.6 } \\
\text { (snrk2 triple) }\end{array}$ & SnRK2 & $\begin{array}{l}\text { - Reduced fresh weight } \\
\text { - Reduced stem height } \\
\text { - Reduced leaf surface area } \\
\text { - Stunted root growth } \\
\text { - Enhanced leaf emergence on plates }\end{array}$ & {$[32,33,67]$} & $\begin{array}{l}\text { - Increased cuticle permeability } \\
\text { - Thinner cell walls } \\
\text { - Decreased lignin and crystalline cellulose } \\
\text { content }\end{array}$ & {$[78,81]$} \\
\hline A. thaliana & $a b i 1-1$ & PP2C & $\begin{array}{l}\text { - Enhanced hyponastic response } \\
\text {-Disturbed root meristem maintenance }\end{array}$ & {$[59,61]$} & $\begin{array}{l}\text { - Increased stomatal index } \\
\text { - Increased cuticle permeability } \\
\text { - Fail to induce ectopic protoxylem in } \\
\text { presence of ABA }\end{array}$ & {$[72-74,78]$} \\
\hline A. thaliana & abi2-1 & PP2C & -Disturbed root meristem maintenance & [61] & - Increased stomatal index & [72] \\
\hline A. thaliana & abi3 & $\mathrm{ABI} 3$ & $\begin{array}{l}\text { - Enhanced hyponastic response } \\
\text { - Disturbed root meristem maintenance }\end{array}$ & {$[59,61]$} & - Decreased suberin formation & [76] \\
\hline A. thaliana & abi4 & $\mathrm{ABI} 4$ & $\begin{array}{l}\text { - Glucose insensitivity } \\
\text { - Enhanced lateral root formation and } \\
\text { growth }\end{array}$ & {$[70,82]$} & - Decreased suberin formation & [76] \\
\hline A. thaliana & abi5 & ABI5 & -Disturbed root meristem maintenance & [61] & - Decreased suberin formation & [76] \\
\hline A. thaliana & $\begin{array}{l}\text { cyp707a1 } \\
\text { cyp707a3 }\end{array}$ & CYP707A & & & - Decreased stomatal index and density & [72] \\
\hline S. lycopersicum & $h p 3$ & ZEP & - Increased number of chloroplasts & [10] & & \\
\hline S. lycopersicum & notabilis & NCED & $\begin{array}{l}\text { - Reduced leaf surface area } \\
\text { - Reduced dry leaf weight } \\
\text { - Short hypocotyls after dark germination }\end{array}$ & [84-88] & $\begin{array}{l}\text { - Increased stomatal index and density } \\
\text { - Altered composition of cutin and } \\
\text { cutilcilar waxes } \\
\text { - Decreased level of cutin }\end{array}$ & [89-91] \\
\hline S. lycopersicum & flacca & Moco sulfurylase & $\begin{array}{l}\text { - Reduced leaf surface area } \\
\text { - Reduced dry leaf weight } \\
\text { - Reduced fruit size } \\
\text { - Reduced assimilation rate } \\
\text { - Increased number of chloroplasts } \\
\text { - Enhanced ethylene evolution rate }\end{array}$ & {$[10,84-86,88,92,93]$} & $\begin{array}{l}\text { - Increased stomatal index and density } \\
\text { - Altered composition of cutin and } \\
\text { cutilcilar waxes } \\
\text { - Decreased level of cutin }\end{array}$ & [89-91] \\
\hline
\end{tabular}


Table 1. Cont.

\begin{tabular}{|c|c|c|c|c|c|c|}
\hline \multirow{2}{*}{ Species } & \multirow{2}{*}{ Mutant } & \multirow{2}{*}{ Gene Function } & \multicolumn{2}{|c|}{ Growth } & \multicolumn{2}{|l|}{ Development } \\
\hline & & & Phenotypes & Ref. & Phenotypes & Ref. \\
\hline S. lycopersicum & sitiens & $\begin{array}{c}\text { abscisic aldehyde } \\
\text { oxidase }\end{array}$ & $\begin{array}{l}\text { - Stunted growth } \\
\text { - Stunted hypocotyls after dark } \\
\text { germination } \\
\text { - Enhanced lateral root formation } \\
\text { - Enhanced assimilation rate } \\
\text { - Increased number of chloroplasts }\end{array}$ & {$[10,84,87,88,92-95]$} & $\begin{array}{l}\text { - Inceased stomatal index and density } \\
\text { - Altered composition of cutin and } \\
\text { cutilcilar waxes } \\
\text { - Decreased level of cutin }\end{array}$ & {$[88,96,97]$} \\
\hline P. sativum & wilty & $\begin{array}{c}\text { xanthin } \\
\text { dehydrogenase }\end{array}$ & - Enhanced lateral root formation & [94] & & \\
\hline Z. mays & vp5 & PDS & $\begin{array}{l}\text { - Stunted root growth } \\
\text { - Enhanced ethylene evolution rate }\end{array}$ & [98] & & \\
\hline O. sativa & oszep & ZEP & $\begin{array}{l}\text { - Enhanced shoot growth after } \\
\text { submergence }\end{array}$ & [99] & & \\
\hline O. sativa & osaba2 & $\begin{array}{c}\text { xanthin } \\
\text { dehydrogenase }\end{array}$ & $\begin{array}{l}\text { - Enhanced stem height } \\
\text { - Overaccumulation of ROS }\end{array}$ & [13] & & \\
\hline O. sativa & ospyl1/4/6 & PYR/PYL/RCAR & $\begin{array}{l}\text { - Enhanced panicle length } \\
\text { - Enhanced fresh weight }\end{array}$ & [36] & & \\
\hline H. vulgare & $A z 34$ & $\begin{array}{c}\text { Moco } \\
\text { biosynthesis }\end{array}$ & - Decreased net assimilation rates & {$[22,93]$} & & \\
\hline
\end{tabular}




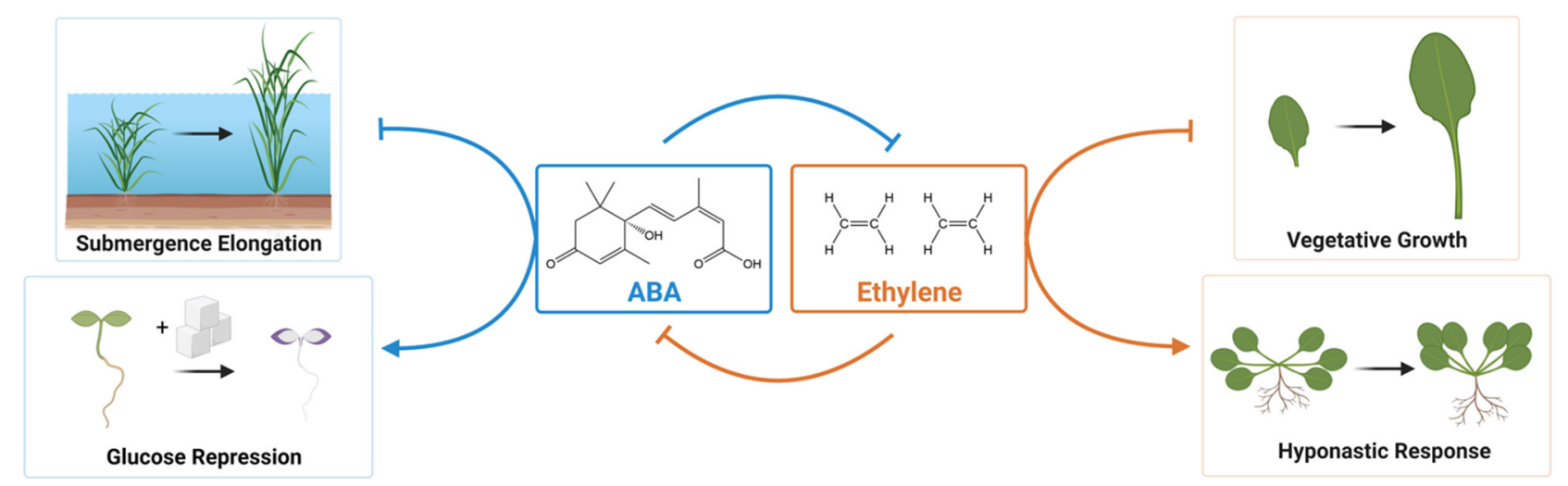

Figure 1. Regulation of plant growth by ABA and Ethylene antagonism. ABA and ethylene function in a mutually antagonistic way to regulate various aspects of plant growth. A prerequisite for shoot elongation in rice is ABA catabolism, which requires ethylene action. High concentrations of glucose are known to result in the growth arrest of Arabidopsis seedlings. This arrest depends on ABA synthesis and signaling and is antagonized by ethylene. Ethylene accumulation is thought to inhibit vegetative growth. One key role of basal ABA is to inhibit ethylene biosynthesis in growing plants. Ethylene signaling promotes hyponastic responses in Arabidopsis, which are antagonized by ABA. Figure created with BioRender (https: / / biorender.com/, accessed on 27 November 2021).

\subsection{Halt! Who Grows There? Growth Inhibition by Basal ABA}

The outcome of basal ABA in growth inhibition should be seen as growth promotion in ABA-deficient and insensitive mutants. Growth promotion of these mutants is observed in local tissues or under particular conditions. Hyponastic growth is the upward bending of leaves that involves growth promotion of cells at the abaxial side. This growth is an adaptive strategy of plants to changing environments, such as submergence and shade avoidance [100]. In Arabidopsis, ABA-deficient (aba1, aba2, aba3) and ABA-insensitive (abi1, abi3) mutants show enhanced hyponastic growth of petioles, which are visible as increases in petiole angles [59]. The petiole angle of the wild type decreases when exogenous ABA is applied. Whereas the application of fluridone, an inhibitor of phytoene desaturases to block metabolite accumulation upstream of ABA biosynthesis, increases the petiole angle. The local growth inhibition by ABA at the petiole is antagonistic to ethylene, which promotes hyponastic growth [59] (Figure 1). It is noteworthy that different Arabidopsis accessions display differential growth responses to these hormones [59]. In Rumex, hyponastic growth is a critical avoidance response to complete submergence [101]. Submergence-induced ABA decreases are a critical step to elongate the shoot in flooding tolerance [102]. The decrease of ABA under submergence is a prerequisite for ethylene and gibberellin action [101]. The shoot growth of osaba1 is enhanced compared with wild type when rice seedlings are submerged [99]. Submergence-induced rapid decrease of ABA is associated with the induction of OsABA8ox1 encoding ABA 8'-hydroxylase [99]. Importantly, submergence-induced ABA decrease is ethylene dependent (Figure 1). Recently, Toriyama et al. reported that a moss RAF-like kinase orthologous to Arabidopsis CONSTITUTIVE TRIPLE RESPONSE1 (CTR1) is required for both ethylene-induced submergence response and ABA-dependent SnRK2 activation [103]. These collectively indicate ABA-ethylene interaction in submerged plants are at both metabolism and signaling levels.

Some ABA-deficient and insensitive mutants of rice show enhanced growth. Rice osaba 2 mutants defective in the xanthoxin dehydrogenase are viable in standard conditions. Interestingly, the plant heights of these mutants are taller than wild type, which is a typical and expected phenotype of mutants defective in growth inhibitors [13]. Although showing excessive growth, the osaba 2 mutants do not appear to be healthy. These mutants were identified as a lesion mimic mutant showing spontaneous cell death with an overaccumu- 
lation of reactive oxygen species (ROS). The phenotype of osaba2 mutants indicates basal ABA plays a role in suppressing ROS production and growth under normal conditions. Some multigenic mutants of rice ABA receptors show increased growth compared to wild type [36]. The rice genome encodes 13 ABA receptors structurally divided into two groups: group I and II [36]. Miao et al. (2018) found that a particular combination of multigenic mutants from Group I receptors grows better and produces greater yield than wild type. Thus, the role of $\mathrm{ABA}$ in growth and stress tolerance is genetically separable at the signaling level in rice. In contrast, ABA-hypersensitive Arabidopsis lines such as the PP2C triple mutants hab1 abi1 abi2 and hab1 abi1 pp2ca show reduced size compared to wild type [80]. Stunted growth of ABA hypersensitive mutants agrees with the role of ABA in growth inhibition. This phenotype is readily explained by a constitutive activation of stress-related ABA genes, facilitating a stress response even in non-stressful environments [80].

One explanation for the stunted growth of ABA-related mutants is an increased sensitivity to environmental factors. Mutants are exposed to stresses more sensitively than wild type due to a lack of stress resistance mechanisms. ABA-deficient mutants of tomato grow faster and taller with an increased number of leaves when grown under mist [84]. Similarly, Arabidopsis ABA-deficient aba2 mutant and snrk2 triple mutants show enhanced growth on agar plates, which are relatively humid compared to standard soil conditions [67]. Excess growth of $a b a 2$ and snrk2 triple mutants is associated with increased respiration through the tricarboxylic acid cycle [67]. In ABA-deficient mutants of both tomato and Arabidopsis, a characteristic aspect of growth enhancement is the increase in the leaf numbers $[67,84]$. Initiation of leaf formation is a well-controlled process and used for determining biological time for flowering. It is particularly interesting to understand the mechanism of how basal ABA regulates leaf initiation. Interestingly, the increased leaf number was not observed in an ABA-insensitive quadruple areb mutant, suggesting that the ABA signaling to negatively regulate leaf initiation is SnRK2-dependent, but independent of AREB-mediated transcription [67].

High concentrations of exogenous ABA inhibit lateral root (LR) growth in Arabidopsis [104]. Ethylene and auxin act downstream of ABA in the regulation of Arabidopsis root elongation [104]. Arabidopsis ABI4 AP2 TFs play an important role in inhibiting LR growth [82]. The abi4 mutant enhanced LR formation and growth, which is characterized by increased LR density and elongated LRs. This mechanism involves counteracting ABA and $C K$ action to regulate expression of $A B I 4$, which in turn disturbs auxin transport [82]. As mentioned above, tomato sit and pea wilty mutants increase LR, indicating low concentrations of ABA can inhibit the formation of LR [94]. The mechanism for ABA-mediated inhibition of LR growth is dynamic and alters depending on time. The inhibition of wild-type LR growth is alleviated by a prolonged ABA treatment, while this recovery is delayed in the pyl8 mutant [105]. This indicates that PYL8 is required for the recovery of LR growth from ABA inhibition in a prolonged period. This involves the PYL8-MYB77 interaction to induce auxin-responsive genes independently of SnRK2 [105]. Consistent with this mechanism, application of auxin rescued the delayed recovery phenotype of the pyl8 mutant [105].

\subsection{Debunking a Myth: Growth Promotion by ABA}

Unsurprisingly, there are ample reports indicating a role for ABA in growth promotion [5]. In this section, we summarize the negative effect of ABA deficiency and insensitivity on growth. The promotive effect of ABA on growth should be observed as smaller plants when ABA biosynthesis or signaling is genetically blocked. Importantly, applying low concentrations of exogenous ABA rescues the stunted growth of ABA-deficient mutants $[68,85]$. ABA-deficient Arabidopsis and tomato mutants show a stunted shoot growth and reduced fresh weight compared to wild type [60,65,77,95]. Furthermore, ABA-insensitive Arabidopsis lines such as higher order pyl112458 sextuple, pyl duodecuple mutants and snrk2.2 snrk2.3 snrk2.6 mutants also display the dwarfed plant phenotype [32,35,37]. In agreement with this, Arabidopsis plants overexpressing SnRK2.6 were shown to have an increase in 
biomass compared to wildtype [106]. One cause of the stunted growth in ABA-related mutants is due to an overproduction of ethylene (Figure 1). Ethylene overproduction is observed in ABA-deficient mutants of tomato and Arabidopsis $[69,85,86]$. Blocking ethylene action by genetically introducing ethylene insensitivity partially reverts the stunted shoot growth of these ABA-deficient mutants $[68,69,85]$. This indicates that a role of basal $\mathrm{ABA}$ in the promotion of growth is to negatively regulate ethylene biosynthesis. The same mechanism is also applicable to maize root growth under low water potential [98]. Importantly, the authors conclude that ABA-mediated ethylene suppression is only part of its effect on vegetative growth; there also exists an ethylene-independent role for ABA.

A positive role of $\mathrm{ABA}$ in the primary root growth is to properly maintain the root meristem. This involves two modes of action; inhibiting cell division of quiescent centre (QC) and suppressing stem cell differentiation, both of which are required for proper meristem functions [61]. Both ABA-deficient (aba1, aba2, aba3) and insensitive (abi1-1, abi2-1, $a b i 3$ and abi5, but not abi4) mutants show enhanced cell division in QC. Importantly, the treatment of an ABA biosynthesis inhibitor fluridone also enhances cell division in $\mathrm{QC}$, which is reversed by co-application of a low concentration of ABA [61]. A pharmacological experiment suggests that ABA-mediated inhibition of QC cell division is independent of ethylene, although ethylene promotes cell division in QC [61].

Grafting experiments indicate that shoot-derived ABA regulates root growth that involves inhibition of LR development and increased root to shoot ratio [94]. The roots of ABA-deficient mutants have increased indole-3-acetic acid (IAA) levels, suggesting the function of ABA to promote root growth involves the decrease the root auxin levels [94]. In Arabidopsis, the regulation of root elongation by exogenous ABA is biphasic. Low concentrations of exogenous ABA promote root growth, while high concentrations inhibit root growth [107].

Hypocotyl growth is achieved solely by cell elongation [108]. The hypocotyl elongates in the dark, while its growth is inhibited in the light. This dark-induced mode of growth is termed skotomorphogenesis. Humplik et al. (2015) reported that etiolated seedlings of sit and not mutants show short hypocotyls [87]. These phenotypes are rescued by applying low doses of exogenous $\mathrm{ABA}$, suggesting that these processes are associated with the growth promotion by ABA in darkness. The short hypocotyl phenotype of Arabidopsis ABA-deficient mutants is also rescued by the application of low concentrations of ABA [62]. In these tomato and Arabidopsis mutants, authors discuss a defect in cell differentiation or faulty induction of cell expansion. Tomato ABA-deficient mutants show decreased expression of $S I K R P 1$ and SlKRP3, blocked endoreduplication, and elevated CKs. In Arabidopsis, ABA induces the expression of ICK1/KRP1, which is thought to antagonize CDKA [109]. In plants impaired in ABA biosynthesis or signal transduction, endoreduplication is affected, resulting in reduced cell expansion. This may be a cause of the reduced rosette size in ABA-deficient and insensitive lines.

ABA promotes fruit growth and maturation. Fruit ripening is categorized into two types; climacteric and non-climacteric, based on the nature of respiration and ethylene dependence. ABA promotes both climacteric and non-climacteric fruit ripening $[110,111]$. In tomato, a climacteric fruit, ripening is accelerated by knock-down of a negative regulator of ABA signaling, SIPP2C1, or by overexpressing an ABA receptor, SIPYL9 [112,113]. Pharmacological experiments demonstrate that ABA promotes tomato fruit ripening via induction of ethylene synthesis [114]. Consistently, SIPP2C1 RNAi lines show earlier ethylene production [112]. On the other hand, flc and flc not mutants produced smaller fruits [86]. This indicates that ABA promotes fruit growth. Interestingly, fruits of the severe ABA-deficient flc not double mutant, but not the flc single mutant, over-produce ethylene. This indicates that basal ABA blocks ethylene over-production, which is opposite to the induction of ethylene synthesis by ABA signaling reported in Zhang et al. (2018) [112]. Thus, crosstalk between ABA and ethylene can be positive or negative, depending on the type of tissue or stage of development studied. 
Aside from stomatal-dependent gas exchange influencing photosynthesis, ABA regulates central metabolism and nutritional signaling, such as carbon metabolism and sugar signaling. Genetic screening for glucose-mediated inhibition of Arabidopsis seedling growth identified $a b a 2$ and abi4 mutants as glucose insensitive [70]. This indicates that glucose mediated growth inhibition requires ABA biosynthesis and ABI4 function. This ABA-mediated growth inhibition is antagonized by ethylene signaling [89] (Figure 1).

ABA regulates carbon metabolism and transport that impacts growth. High concentrations of $\mathrm{ABA}$ mimic stress conditions, which negatively regulate photosynthesis and carbon assimilation. This is supported by down-regulation of nuclear and chloroplast encoded photosynthesis genes by exogenous ABA $[1,115,116]$. Also, ABA application promotes accumulation of soluble sugars [117]. ABA Moreover, overexpression of apple $M d A R E B 2$ induces expression of MdSUT2, a sucrose transporter gene, via direct binding to its promoter [118]. On the other hand, the role of basal ABA on photosynthesis is controversial, possibly depending on the context. Tomato sit mutants show an increased net assimilation rate when compared with wild type under non-stressed conditions [92]. Tomato fla and barley Az34 both have a defect in MoCo biosynthesis, which decreased net assimilation rates [93]. Moreover, it is differentially affected by relative humidity in which net assimilation of Az34, but not fla, is negatively affected by low humidity. The Arabidopsis aba1 mutants show a decreased photosynthesis (PSII) activity [8].

One characteristic phenotype of ABA-deficient mutants is a defect in chloroplast biogenesis. Arabidopsis aba1 mutants show an increased number of chloroplasts with aberrant ultrastructure $[8,10]$. The aba1 mutants over-accumulate zeaxanthin and disturb the xanthophyll content, which may affect chloroplast biogenesis and function. The increase of chloroplast numbers and its aberrant ultrastructure can also be seen in the tomato high-pigment3 ( $h p 3$ ) mutant defective in ZEP. Interestingly, similar defects in chloroplast biogenesis can also be seen in fla and sit mutants of tomato [10]. These indicate that basal ABA, rather than zeaxanthin over-accumulation, is required for maintaining proper chloroplast biogenesis and functions. It will be interesting to investigate how disturbed chloroplast biogenesis impacts plant growth as well as sugar and energy metabolism in ABA-related mutants under both non-stressed and stressed conditions.

\section{Role of ABA in Plant Development}

To adapt their growth under a changing environment, land plants have developed specialized cells and tissues that are optimized for gas exchange and water transport, while minimizing water loss and pathogen attacks. In aerial organs, a layer of hydrophobic compounds, mainly cutin and waxes, cover the epidermis to prevent water loss and protect from pathogens, while stomata, which are epidermal pores, control water and gas exchange [119]. Below ground, hydrophobic compounds such as suberin and waxes surround the mature endodermis of the roots, to control water and nutrient movements from the soil into the xylem vessels of the stele [120]. Here, we review the role that basal ABA plays in the development of these tissues under non-stressed conditions (see also Figure 2 and Table 1). The role of ABA in seed and plant dormancy, somatic embryogenesis, senescence and fruit ripening has been recently reviewed and will not be covered here $[2,3,121-123]$. 


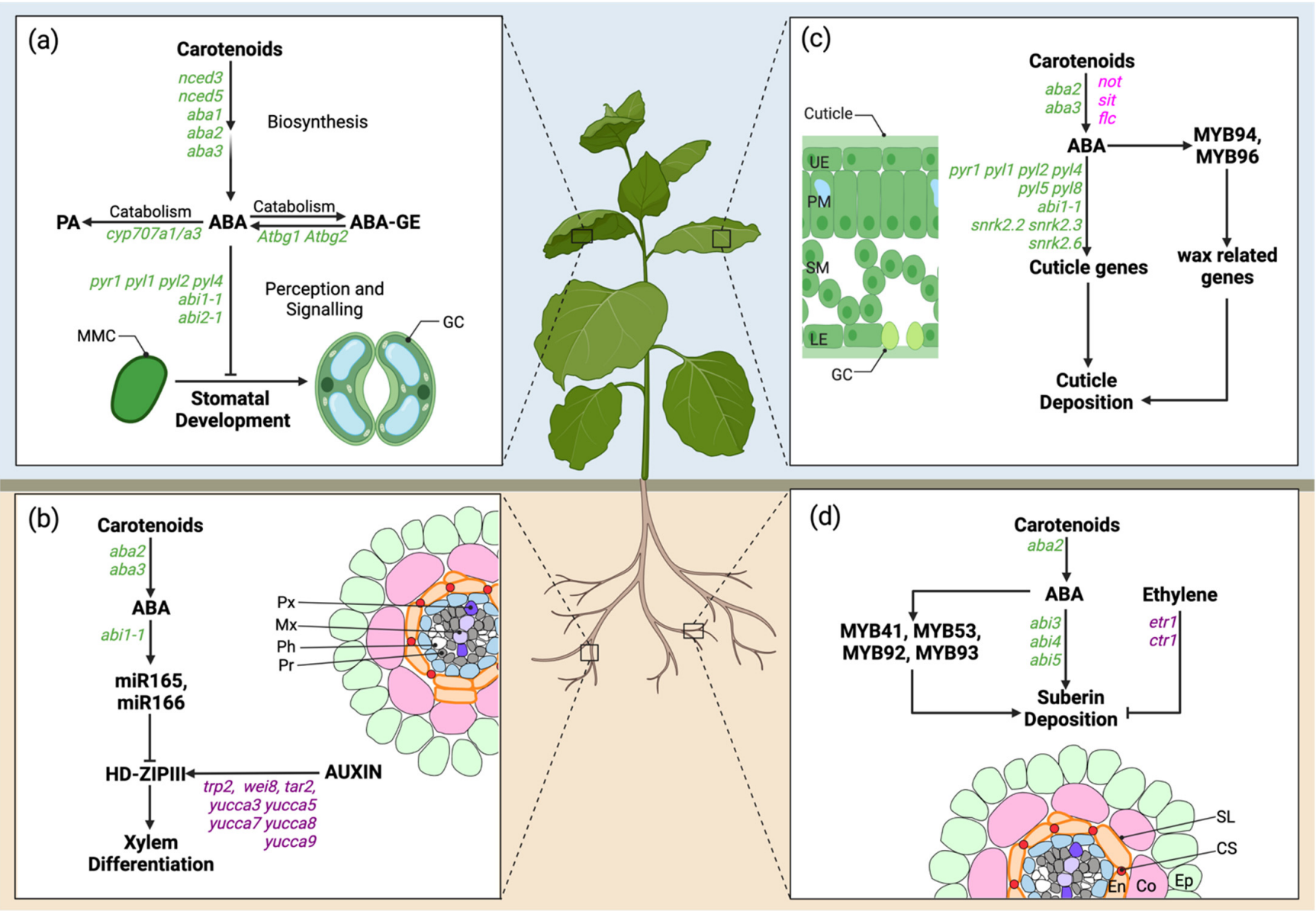

Figure 2. Overview of the role of basal ABA in stomata development, cuticle and suberin deposition, and xylem differentiation. Genetic analysis of ABA synthesis and signalling demonstrates a role for basal ABA in stomatal development, protoxylem differentiation, and deposition of cuticle and suberin. (a) ABA biosynthetic and signalling mutants show increased stomatal index or density, while ABA catabolism mutant display decreased stomatal index or density, indicating a negative role for ABA in stomatal development. (b) ABA promotes protoxylem differentiation through upregulation of miR165/166 in the endodermis, which downregulates HD-ZIP III in the stele. Xylem differentiation is disrupted in ABA biosynthesis and signaling mutants, which develop discontinuous metaxylem strands. (c) ABA promotes cutin deposition, by indirectly regulating wax and cutin-related genes. In Arabidopsis and tomato ABA biosynthetic mutants, hydrophobic cutin and wax layers are reduced. In Arabidopsis, ABA signaling mutants display increased cuticle permeability. (d) ABA positively regulates suberin deposition. ABA biosynthetic and signaling mutants show decreased suberin accumulation. ABA regulates several MYB TFs, which in turn promote suberin or cuticle deposition. Other hormones also regulate these processes: ABA regulates suberin accumulation antagonistically to ethylene, while acting in parallel with auxin in xylem differentiation. ABA related mutants are shown in green for Arabidopsis and in magenta for tomato; ethylene and auxin mutants are shown in lilac/purple. Panels (a) and (c) abbreviations: MMC, meristemoid mother cell; GC, guard cell; UE, upper epidermis; PM, palisade mesophyll; SM, spongy mesophyll; LE, lower epidermis. Panels (b) and (d) abbreviations and legend: epidermis (Ep), light green; cortex (Co), light pink; endodermis (En), light orange; suberin lamellae ( $\mathrm{Sl})$, orange; Casparian strip (Cs), red; pericycle (Pe), light blue; procambium (Pr), grey; phloem (Ph), white; protoxylem (Px), purple; metaxylem (Mx), light purple/lilac. Figure created with BioRender (https:/ / biorender.com/, accessed on 27 November 2021).

\subsection{Breath-Taking: ABA Inhibition of Stomatal Development}

Aside from its well-known function in regulating stomata physiology and promoting stomata closure [124], ABA also plays an important role in stomata development. ABA levels inversely correlate with stomata density (number of stomata per unit of area) and index (percentage of stomata cells to the total number of epidermal cells). Genetic analysis 
using ABA metabolism mutants has revealed that ABA inhibits entry of epidermal cells into the stomata development pathway. Several Arabidopsis ABA-deficient mutants (aba1, $a b a 2, a b a 3$ and nced 3 nced5), including mutants with reduced levels of active ABA (Atbg1 Atbg2), display increased stomatal density or index. In contrast, ABA catabolism mutants (cyp707a1 cyp707a3) show decreased stomata density or index $[63,64,66,72,83]$. Similarly, tomato ABA-deficient $f l c$, sit and not mutants have increased stomata density and index [88]. The increased stomata density of ABA biosynthetic mutants can be rescued by application of ABA [72,125] or by expressing ABA biosynthetic genes only in stomata lineage cells, suggesting a cell autonomous ABA-dependent regulation of stomata development [66]. $\mathrm{ABA}$ also decreases guard cell size and is required for pavement cell expansion, suggesting ABA regulates the final size of epidermal cells [72]. Perturbation of the ABA signaling pathway also affects stomata development; the dominant, ABA insensitive abi1- 1 and abi2-1 mutants display increased stomata index [64,72]. Thus, ABA and a functional ABA signaling pathway are required to limit entry of epidermal cell into the stomatal lineage pathway (Figure 2).

In Arabidopsis, stomata development is promoted by the sequential action of three basic helix-loop-helix TFs, SPEECHLESS (SPCH), MUTE and FAMA. The stomatal development pathway is repressed in non-stomatal lineage cells by a family of leucine-rich repeat receptor kinases and coreceptors (TMM, ER, ER-like, SERK). Activation of the receptors by the peptide ligands, EPIDERMAL PATTERNING FACTOR1 (EPF1) and EPF2, repress SPCH through phosphorylation by a MAP kinase signaling cascade $[75,126]$. In Arabidopsis, mutations that decrease the levels of active ABA (Atbg1 Atbg2) correlate with upregulation of $S P C H, M U T E$ and FAMA [83]. In aba2, which was shown to prolong the development of meristemoids and guard mother cell in cotyledons, the expression of $S P C H$ and MUTE is also extended, suggesting a temporal effect of ABA in restricting entry into the stomatal development pathway [72]. However, in nced3 nced5, expression level of SPCH and MUTE was not affected, while EPF2 transcript level was increased, possibly due to the increased number of stomata precursor cells or feedback regulation [66]. Genetic interaction studies between $a b a 2$ and spch or mute indicate that ABA inhibits stomatal development at the level of $S P C H$ [72]. These findings demonstrate that in the absence of stress, ABA-mediated inhibition of stomatal development acts through the well-characterized stomatal development pathway (Figure 2).

Stomatal development is regulated by environmental signals, including light, water, temperature, and $\mathrm{CO}_{2}$ (Reviewed in [75,126,127]). ABA biosynthetic (nced3 nced5 and aba3) as well as perception (pyr1 pyl1 pyl2 pyl4) mutants fail to decrease stomatal density in response to elevated $\mathrm{CO}_{2}$. This phenotype can be complemented by targeted expression of $A B A 3$ or NCED3 in aba3 or nced 3 nced5 stomata lineage cells, respectively, suggesting a cell autonomous mode of action [66]. Thus, inhibition of stomatal development by elevated $\mathrm{CO}_{2}$ requires $\mathrm{ABA}$ as well as a functional ABA signaling pathway in guard cells or its precursors.

Manipulation of CK, auxin, ethylene and BR levels or sensitivity also affects stomata density or patterning mainly acting at the level of $\mathrm{SPCH}$, whose function is well conserved across different plant species [128]. These studies have shown that ABA, jasmonates, and auxin inhibit while CKs and ethylene promote stomata development. In contrast, brassinosteroids (BR) promote stomata development in hypocotyls, while inhibiting stomata formation in cotyledons $[63,90,91,129-135]$. MAPK integrates ABA and BR signaling in the control of stomatal development. While ABA activates MKKK20-MKK5-MPK6 cascade by sequestering $\mathrm{ABI} 1$ phosphatase, which promotes phosphorylation and degradation of $\mathrm{SPCH}$, negative regulation of BIN2 by BR activates YDA-MKK4-MKK5 cascade, which results in phosphorylation and degradation of SPCH $[131,136]$. Crosstalk between several hormone signaling pathways ensures that multiple signals are integrated to regulate stomata development. However, the mechanism by which hormone signaling pathways interact to regulate stomatal development through $\mathrm{SPCH}$ is currently unclear. 


\subsection{You Shall Not Pass! The Role of ABA in Cutin and Waxes Deposition}

The cuticle is a hydrophobic layer covering the epidermis of land plant aerial organs. The cuticle is composed of cutin, an aliphatic polyester, and waxes, which are secreted and deposited on the outer side of the plant cell wall. The cuticle acts as a layer of protection against environmental stress, primarily preventing non-stomatal water loss and pathogen attacks, as well as diffusion of materials across the cell wall $[119,137]$.

Physiological, molecular, and genetic studies have shown that basal ABA promotes the synthesis and deposition of cutin and waxes [71,96,97,138-140]. ABA increases wax content in the cuticle by inducing expression of MYB94 and MYB96, which can directly bind to and positively regulate wax biosynthetic genes $[139,140]$. Furthermore, the cuticles of ABA-deficient mutants ( $a b a 2$ and $a b a 3$ ) display increased permeability and ROS production in Arabidopsis [71]. Similarly, the leaves of tomato ABA-deficient mutants (not, sit, flc) show reduced expression of genes involved in cutin and wax formation, resulting in decreased levels and altered composition of cutin and cuticular waxes [96,97]. These phenotypes were rescued by application of ABA and resemble those displayed by cuticle biosynthesis mutants ( $b d l$ and lacs2), indicating that ABA biosynthesis is required to promote cuticle development even in the absence of stress $[71,96,97]$ (Figure 2).

Mutations affecting core components of the ABA signaling pathways (pyr1 pyl1 pyl2 pyl4 pyl5 pyl8, abi1-1, and snrk2.2 snrk2.3 snrk2.6) also result in increased cuticle permeability [78]. Several cuticle-related genes encoding for biosynthetic enzymes and transporters, as well as positive (MYB94, MYB96) and negative (DEWAX) regulators of wax synthesis and cutin deposition are differentially regulated in ABA metabolic (aba3, cyp707a1 cyp707a3) or signaling (snrk2.2 snrk2.3 snrk2.6, abf2 abf3 abf4, and abi1-1) mutants [78,141]. However, mutations in ABA signaling components downstream of SnRK2 (abf2 abf3 abf4) did not show defects in cuticle permeability, suggesting ABA signaling may indirectly regulate cutin deposition through activation of MYBs and negative regulation of DEWAX [78]. Wax-related genes, including CER6, have ABA-responsive elements in their promoters and are induced by $\mathrm{ABA}$, thus it is possible that $\mathrm{ABA}$ directly regulates wax synthesis (Reviewed in [142]) (Figure 2). In the moss Physcomitrella patens, ABA negatively regulates the expression of cuticle-related genes, suggesting different evolution of ABA function during cuticle deposition in flowering and non-flowering plants [78].

Abiotic and biotic stresses alter the thickness and composition of the cuticle in several species. While increased cuticle thickness promotes tolerance to abiotic stresses such as drought, altered composition and amount of cuticle have different effects during plant interaction with pathogens; in some cases it promotes plant tolerance to biotic stresses, while in others it has an inhibitory effect (reviewed in [143]). Cutin also mediates plant response to osmotic stress by regulating ABA biosynthesis. Following osmotic stress, mutants impaired in cutin biosynthesis show reduced induction of ABA biosynthesis genes leading to decreased ABA accumulation and reduced tolerance to osmotic stress, although the mechanism is unclear [144]. Thus, not only does cutin play a protective role against environmental stress, but it is also required for osmotic stress induction of ABA biosynthesis. By regulating cuticle deposition, ABA plays different roles in plant response to biotic and abiotic stresses.

\subsection{Xylem Differentiation: $A B A$ and Auxin Act in Concert}

Water transport from the root to the shoot is mediated by the xylem. Made of cellulose, hemicellulose and lignin, the secondary cell wall (SCW) is deposited in the xylem and provides support and strength to withstand the negative pressures of water transport. In Arabidopsis roots, the protoxylem is composed of spiral or annual SCW and develops at the periphery of the stele, while the metaxylem is made of reticulated or pitted walls and forms in the center of the stele [145]. Xylem identity is specified by the interplay between class III homeodomain leucine zipper (HD-ZIP III) TFs and microRNA165 (miR165)/miR166. $\mathrm{miR} 165 / \mathrm{miR} 166$ are expressed in the endodermis and move to the xylem to restrict HD-ZIP III expression pattern in a dose-dependent manner, with protoxylem specified by low 
HD-ZIPIII level in the periphery and metaxylem by high level of HD-ZIPIII in the middle of the stele [146,147].

Recent studies have shown that ABA is required for SCW deposition and specification of xylem identity. In Arabidopsis and tomato roots, exogenous ABA induces early protoxylem differentiation at the root tip as well as protoxylem formation in place of metaxylem further away from the root tip. In contrast, ABA deficiency, induced either genetically ( $a b a 2, a b a 3)$ or chemically (fluridone), disrupts xylem development and results in the formation of discontinued metaxylem strands $[73,74]$. Furthermore, impaired ABA perception and signaling mutants (abi1-1, pyr1 pyl1 pyl2 pyl4) fail to induce ectopic protoxylem in the presence of ABA [73,74]. Mechanistically, ABA induces miR165A/166B through the core ABA signaling pathway. Targeted inhibition of ABA signaling in the endodermis, but not in the stele, is sufficient to inhibit xylem differentiation via miR165 induction $[73,74]$ (Figure 2). These studies show that ABA acts in the endodermis and upstream of miR165/166-HD-ZIP III module to promote protoxylem differentiation in the stele in a non-cell autonomous manner. Interestingly, reduced ABA signaling in the epidermis or columella can also affect xylem differentiation, implying the existence of another non-cell autonomous ABA-dependent mechanism [73,74]. A similar switch in xylem cell identity is also observed in roots exposed to osmotic and water stress, which elevate endogenous ABA levels [73,74]. Under water stress, an increase in miR165 restricts PHABULOSA (PHB) expression, leading to an increase in protoxylem development and a switch from a pitted to a reticulate metaxylem [73]. In maize, embolism induced by water stress was more frequent in metaxylem compared to protoxylem, and an increase in the number and thickness of vessels was observed also in other plant species subjected to water stress, suggesting that this developmental switch may confer an advantage under low water conditions [148-151].

Auxin, CKs, JA and BR also regulate vascular patterning and xylem differentiation in the stele (Reviewed in [145]). In the stele, auxin biosynthesis mutants (trp2, wei8 tar2, quintuple yucca) show defects in metaxylem development [152], while inhibition of auxin signaling completely inhibits xylem development; the latter can be partially restored by exogenous $\mathrm{ABA}$, suggesting $\mathrm{ABA}$ and auxin promote xylem differentiation through independent pathways [74]. In the stele, auxin biosynthesis is required for the induction of $H D$-ZIP III genes [152], which bind to the promoter of $M P$, a master regulator of vascular development, and its negative regulator $I A A 20$, to regulate metaxylem formation [153]. These studies show that $\mathrm{ABA}$ and auxin regulate xylem differentiation independently: ABA induces miR165A in the endodermis, whereas auxin activates HD-ZIP III in the stele (Figure 2).

In the inflorescence stem, ABA was shown to promote SCW deposition, which is controlled by a set of NAC TFs, including NAC SECONDARY WALL THICKENING PROMOTING FACTOR 1 (NST1)/ANAC043. Genes related to SCW synthesis are downregulated in inflorescence stem of ABA-deficient (aba2) and signaling (snrk2.2 snrk2.3 snrk2.6) mutants. Accordingly, these mutants have thinner cell walls and decreased lignin and crystalline cellulose content [81]. ABA regulation of SCW formation requires phosphorylation of NST1 by SnRK2s. Interestingly, the SnRK2-mediated phosphorylation site is conserved in NST1 orthologs in dicots, but not in monocots, suggesting different regulatory mechanisms controlling SCW deposition in monocots and dicots [81]. Overexpression of NCED6 and NCED9, which induce the expression of SCW-related genes, did not increase lignification and SCW deposition, suggesting ABA alone is not sufficient to promote SCW deposition.

\subsection{A Corky Story: Antagonistic Role of ABA and Ethylene in Suberin Deposition}

Suberin is a phenolic and aliphatic heteropolymer that can be found in various tissues including cork, seed coats, tree bark, root periderm and root endodermis in higher plants. In the endodermis, suberin lamellae are deposited to create SCW that acts to shift the endodermis from an actively absorbing tissue to a protected endodermis. This action depends 
on the developmental stage as well as hormone signals that are based off environmental stimuli [76].

Several studies have shown that exogenous application of ABA induces the expression of suberin-related genes and increases suberin deposition in the endodermis, while triggering ectopic suberin deposition in root tips and in potato tubers [76,154-159]. An essential role of basal ABA in endodermal suberization has been supported by genetic studies. A dramatic decrease in suberin formation is shown in ABA-deficient (aba2) and signaling (abi3, abi4, abi5) mutants, as well as when ABA signaling is suppressed in the endodermis [76]. ABA-dependent suberin deposition is mediated by MYB41-MYB53-MYB92-MYB93, which are expressed in the endodermis and induced by ABA. A quadruple myb41 myb53 myb92 myb93 mutant shows a nearly complete lack of endodermal root suberin, which could not be rescued by application of ABA [159], whereas overexpression of some MYB TFs results in ectopic suberin accumulation [156,160] (Figure 2). ABA-induced suberin deposition also requires the auxin-regulated GDSL lipases, some of which have been proposed to be involved in suberin degradation while other in ABA-mediated suberin synthesis [159].

While ABA promotes suberin synthesis, ethylene triggers its degradation, as demonstrated by the enhanced deposition of suberin in the ethylene insensitive mutant, etr1, and reduced suberization in the constitutive ethylene signaling mutant, ctr1 [76]. ABA can partially restore suberization in ctr1, suggesting ABA and ethylene signaling may intersect in regulating suberin deposition [76]. A suberin loss-of-function mutant (suberman/myb39) and overexpression line show differential expression of ABA and ethylene signalling genes, which further support ABA and ethylene crosstalk in suberin formation in Arabidopsis [161] (Figure 2).

Depending on the availability of nutrients, suberization can be enhanced or decreased, and this process is under hormonal regulation. Under iron (Fe), manganese (Mn) or zinc $(\mathrm{Zn})$ deficiency, ethylene signalling is induced to inhibit endodermal suberization, whereas deficiencies in sulfur $(S)$, potassium $(K)$ or salt stress activate suberin deposition through ABA signalling [76]. Seed yield, rosette size and weight were reduced in the suberin-deficient mutants [76], phenotypes that are also shown by ABA-deficient mutants, suggesting that ABA regulation of plant growth may be in part linked to its ability to regulate suberin deposition, and thus water and nutrient uptake or retention. Interestingly, using ABA deficient (aba2) and signaling (abi4) mutants, as well as endodermal-specific suppression of ABA signaling, a recent study highlighted the role of the microbiome in modulating suberin deposition, nutrient uptake and plant growth by suppressing ABA responses [162]. Overall, ABA plays direct and indirect roles in the regulation of suberin biosynthesis, accumulation, and deposition in the endodermis in various stressed and non-stressed conditions.

\section{Conclusions and Future Directions}

A considerable amount of research has been conducted to address the role of ABA in regulating stress responses in plants. However, less is known about the role of ABA in modulating plant growth and developmental processes. Here, we reviewed genetic evidence that supports ABA acting as both a positive and negative regulator of growth. Biphasic ABA responses are often observed in which low doses of ABA promote growth, while high doses inhibit it [5,6]. ABA plays roles in regulating central metabolism and chloroplast biogenesis. Crosstalk between ABA and other phytohormones, including auxin, $\mathrm{CK}$, and ethylene is also important for fine-tuning control over growth. The critical function of basal ABA in promoting growth is to negatively regulate ethylene biosynthesis. This ABA-ethylene interaction also plays a major role in regulating local growth responses. In terms of molecular mechanisms, ABA regulates ethylene biosynthesis via multiple different pathways, including transcriptional and post-translational regulations [163]. For example, ABA can inhibit ethylene biosynthesis through ABI4. ABI4 is shown to bind to the promoter of ACS genes and repress their transcription [164]. Auxin and CK pathways have critical roles in regulating cell cycle progression of roots and shoots, and are known to 
interact with ABA signaling components. Overall, phytohormone crosstalk can be positive or negative depending on the tissue and developmental stage being assessed, highlighting a need for specificity and precision in future studies.

ABA also plays key roles in the determination of cell fate and development of tissues that are involved in transpiration and gas exchange, as well as water and nutrient transport, by regulating the biosynthesis of cutin, waxes and suberin. Specifically, genetic evidence supports a negative role for ABA in stomata development, and a positive role in the deposition of shoot epidermal waxes and cutin. ABA also positively regulates suberin deposition in the root endodermis and xylem differentiation in the vasculature of various higher plants. While ABA promotes xylem development non-cell autonomously, it acts in the endodermis to promote suberin deposition in a cell autonomous manner $[143,144,152]$. ABA works synergistically with auxin to promote xylem differentiation, while acting antagonistically with ethylene in suberin deposition. ABA's role in modulating plant growth and stress response is directly linked to its function in regulating chloroplast biogenesis, which affects metabolism including processes required for the development of cells and tissues that are pivotal for nutrient uptake and transpiration.

Despite the data available describing ABA's role in growth and development, there are still outstanding questions to be addressed in the future. Although basal ABA is required for the development of specific tissues, the action of ABA in these cell and tissue types are unknown. Cell- or tissue-type specific transcriptomic studies coupled with ChIP-seq should help elucidate regulatory circuits and identify direct targets of hormone signaling components in different cell and tissue types. This should also aid in understanding mechanisms of cell and non-cell autonomous signaling and is critical to uncover other players as well as evidence of hormone crosstalk. These studies should be accompanied by metabolomic analyses in different tissues and at different stages of development. Most of the studies discussed here were conducted in seedlings, leaves or roots, however there is a little genetic evidence on the role of basal ABA in the development of other organs or at different stages of development. Lastly, to uncover mechanisms of evolution in ABAmediated control of growth and development, it is critical that we extend our knowledge to other plant species.

Author Contributions: All authors contributed to the writing, discussion and editing of the manuscript. B.P.B. and J.P. prepared the Figures. All authors have read and agreed to the published version of the manuscript.

Funding: The financial supports by a Natural Sciences and Engineering Research Council of Canada (NSERC) Discovery Grant RGPIN-2019-04144 and a Canada First Research Excellence Fund (CFREF) grant that established the Plant Phenotyping and Imaging Research Centre (P2IRC) project to EN.

Institutional Review Board Statement: Not applicable.

Informed Consent Statement: Not applicable.

Data Availability Statement: Not applicable.

Conflicts of Interest: The authors declare that they have no conflict of interest.

\section{References}

1. Cutler, S.R.; Rodriguez, P.L.; Finkelstein, R.R.; Abrams, S.R. Abscisic acid: Emergence of a core signaling network. Annu. Rev. Plant Biol. 2010, 61, 651-679. [CrossRef]

2. Nambara, E.; Okamoto, M.; Tatematsu, K.; Yano, R.; Seo, M.; Kamiya, Y. Abscisic acid and the control of seed dormancy and germination. Seed Sci. Res. 2010, 20, 55-67. [CrossRef]

3. Sano, N.; Marion-Poll, A. ABA metabolism and homeostasis in seed dormancy and germination. Int. J. Mol. Sci. 2021, 22, 5069. [CrossRef]

4. Pan, W.; Liang, J.; Sui, J.; Li, J.; Liu, C.; Xin, Y.; Zhang, Y.; Wang, S.; Zhao, Y.; Zhang, J.; et al. ABA and bud dormancy in perennials: Current knowledge and future perspective. Genes 2021, 12, 1635. [CrossRef]

5. Humplik, J.F.; Bergougnoux, V.; van Volkenburgh, E. To stimulate or inhibit? That is the question for the function of abscisic acid. Trends Plant Sci. 2017, 22, 830-841. [CrossRef]

6. Yoshida, T.; Christmann, A.; Yamaguchi-Shinozaki, K.; Grill, E.; Fernie, A.R. Revisiting the basal role of ABA—Roles outside of stress. Trends Plant Sci. 2019, 24, 625-635. [CrossRef] 
7. Seo, M.; Marion-Poll, A. Abscisic acid metabolism and transport. In Advances in Botanical Research, Abscise Acid in Plants; Seo, M., Marion-Poll, A., Eds.; Elsevier: Oxford, UK, 2019; Volume 92, pp. 1-50.

8. Rock, C.D.; Bowlby, N.R.; Hoffmann-Benning, S.; Zeevaart, J.A.D. The aba mutant of Arabidopsis thaliana (L.) Heynh. has reduced chlorophyll fluorescence yields and reduced thylakoid stacking. Plant Physiol. 1992, 100, 1796-1801. [CrossRef]

9. Agrawal, G.K.; Yamazaki, M.; Kobayashi, M.; Hirochika, R.; Miyao, A.; Hirochika, H. Screening of the rice viviparous mutants generated by endogenous retrotransposon Tos17 insertion. Tagging of a zeaxanthin epoxidase gene and a novel OsTATC gene. Plant Physiol. 2001, 125, 1248-1257. [CrossRef]

10. Galpaz, N.; Wang, Q.; Menda, N.; Zamir, D.; Hirschberg, J. Abscisic acid deficiency in the tomato mutant high-pigment 3 leading to increased plastid number and higher fruit lycopene content. Plant J. 2008, 53, 717-730. [CrossRef]

11. Muller, P.; Li, X.P.; Niyogi, K.K. Non-photochemical quenching. A release to excess light energy. Plant Physiol. 2001, 125, 1558-1566. [CrossRef]

12. McAdam, S.A.M.; Sussmilch, F.C.; Brodribb, T.J.; Ross, J.J. Molecular characterization of a mutation affecting abscisic acid biosynthesis and consequently stomatal responses to humidity in an agriculturally important species. AoB Plants 2015, 7, plv091. [CrossRef]

13. Liao, Y.X.; Bai, Q.; Xu, P.Z.; Wu, T.K.; Guo, D.M.; Peng, Y.B.; Zhang, H.Y.; Deng, X.S.; Chen, X.Q.; Luo, M.; et al. Mutation in rice Abscisic Acid2 results in cell death, enhanced disease-resistance, altered seed dormancy and development. Front. Plant Sci. 2018, 9, 405. [CrossRef]

14. Creelman, R.A.; Bell, E.; Mullet, J.E. Involvement of a lipoxygenase-like enzyme in abscisic acid biosynthesis. Plant Physiol. 1992, 99, 1258-1260. [CrossRef]

15. Kitahata, N.; Han, S.Y.; Noji, N.; Saito, T.; Kobayashi, M.; Nakano, T.; Kuchitsu, K.; Shinozaki, K.; Yoshida, S.; Matsumoto, S.; et al. A 9-cis-epoxycarotenoid dioxygenase inhibitor for use in the elucidation of abscisic acid action mechanisms. Bioorg. Med. Chem. 2006, 14, 5555-5561. [CrossRef]

16. Awan, S.Z.; Chandler, J.O.; Harrison, P.J.; Sergeant, M.J.; Bugg, T.D.H.; Thompson, A.J. Promotion of germination using hydroxamic acid inhibitors of 9-cis-epoxycarotenoid dioxygenase. Front. Plant Sci. 2017, 8, 357. [CrossRef]

17. Seo, M.; Aoki, H.; Koiwai, H.; Kamiya, Y.; Nambara, E.; Koshiba, T. Comparative Studies on the Arabidopsis aldehyde oxidase (AAO) gene family revealed a major role of AAO3 in ABA biosynthesis in seeds. Plant Cell Physiol. 2004, 45, 1694-1703. [CrossRef]

18. Schwarz, G.; Mendel, R.R. Molybdenum cofactor biosynthesis and molybdenum enzymes. Annu. Rev. Plant Biol. 2006, 57, 623-647. [CrossRef]

19. Xiong, L.; Ishitani, M.; Lee, H.; Zhu, K.J. The Arabidopsis LOS5/ABA3 locus encodes a molybdenum cofactor sulfurase and modulates cold stress-and osmotic stress-responsive gene expression. Plant Cell 2001, 13, 2063-2083.

20. Sagi, M.; Scazzocchio, C.; Fluhr, R. The absence of molybdenum cofactor sulfuration is the primary cause of the flacca phenotype in tomato plants. Plant J. 2002, 31, 305-317. [CrossRef]

21. Watanabe, S.; Sato, M.; Sawada, Y.; Tanaka, M.; Matsui, A.; Kanno, Y.; Hirai, M.Y.; Seki, M.; Sakamoto, A.; Seo, M. Arabidopsis molybdenum cofactor sulfurase ABA3 contributes to anthocyanin accumulation and oxidative stress tolerance in ABA-dependent and independent ways. Sci. Rep. 2018, 8, 16592. [CrossRef]

22. Walker-Simmons, M.; Kudma, D.A.; Warner, R.L. Reduced accumulation of ABA during water stress in a molybdenum cofactor mutant of barley. Plant Physiol. 1989, 90, 728-733. [CrossRef]

23. Okamoto, M.; Kuwahara, A.; Seo, M.; Kushiro, T.; Asami, T.; Hirai, N.; Kamiya, Y.; Koshiba, T.; Nambara, E. CYP707A1 and CYP707A2, which encode ABA 8'-hydroxylases, are indispensable for a proper control of seed dormancy and germination in Arabidopsis. Plant Physiol. 2006, 141, 97-107. [CrossRef]

24. Okamoto, M.; Tanaka, Y.; Abrams, S.R.; Kamiya, Y.; Seki, M.; Nambara, E. High humidity induces ABA 8'-hydroxylase in stomata and vasculature to regulate local and systemic ABA responses in Arabidopsis. Plant Physiol. 2009, 149, 825-834. [CrossRef]

25. Umezawa, T.; Okamoto, M.; Kushiro, T.; Nambara, E.; Oono, Y.; Kobayashi, M.; Koshiba, T.; Kamiya, Y.; Shinozaki, K. CYP707A3, a major ABA 8'-hydroxylase involved in dehydration and rehydration response in Arabidopsis thaliana. Plant J. 2006, 46, 171-182. [CrossRef]

26. Todoroki, Y.; Ueno, K. Development of specific inhibitors of CYP707A, a key enzyme in the catabolism of abscisic acid. Curr. Med. Chem. 2010, 17, 3230-3244. [CrossRef]

27. Abrams, S.R.; Loewen, M.C. Chemistry and chemical biology of ABA. In Advances in Botanical Research, Abscise Acid in Plants; Seo, M., Marion-Poll, A., Eds.; Elsevier: Oxford, UK, 2019; Volume 92, pp. 315-340.

28. Saito, S.; Okamoto, M.; Shinoda, S.; Kushiro, T.; Koshiba, T.; Hirai, N.; Sakata, K.; Nambara, E.; Mizutani, M. A plant growth retardant uniconazole is a potent inhibitor of ABA catabolism in Arabidopsis. Biosci. Biotechnol. Biochem. 2006, 70, 1731-1739. [CrossRef]

29. Ma, Y.; Szostkiewicz, I.; Korte, A.; Moes, D.; Yang, Y. Regulators of PP2C phosphatase activity function as abscisic acid sensors. Science 2009, 324, 1064-1068. [CrossRef]

30. Park, S.Y.; Fung, P.; Nishimura, N.; Jensen, D.R.; Fujii, H. Abscisic acid inhibits type 2C protein phosphatases via the PYR/PYL family of START proteins. Science 2009, 324, 1068-1071. [CrossRef]

31. Fujii, H.; Chinnusamy, V.; Rodrigues, A.; Rubio, S.; Antoni, R.; Park, S.Y.; Cutler, S.R.; Sheen, J.; Rodriguez, P.L.; Zhu, J.K. In vitro reconstitution of an ABA signaling pathway. Nature 2009, 462, 660-664. [CrossRef]

32. Fujii, H.; Zhu, J.K. Arabidopsis mutant deficient in three abscisic acid-activated protein kinases reveals critical roles in growth, reproduction, and stress. Proc. Natl. Acad. Sci. USA 2009, 106, 8380-8385. [CrossRef] 
33. Nakashima, K.; Fujita, Y.; Kanamori, N.; Katagiri, T.; Umezawa, T.; Kidokoro, S.; Maruyama, K.; Yoshida, T.; Ishiyama, K.; Kobayashi, M.; et al. Three Arabidopsis SnRK2 Protein Kinases, SRK2D/SnRK2.2, SRK2E/SnRK2.6/OST1 and SRK2I/SnRK2.3, involved in ABA signaling are essential for the control of seed development and dormancy. Plant Cell Physiol. 2009, 50, 1345-1363. [CrossRef]

34. Suzuki, M.; McCarty, D. Functional symmetry of the B3 network controlling seed development. Curr. Opin. Plant Biol. 2008, 11, 548-553. [CrossRef]

35. Gonzalez-Guzman, M.; Pizzio, G.A.; Antoni, R.; Vera-Sirera, F.; Merilo, E.; Bassel, G.W.; Fernández, M.A.; Holdsworth, M.J.; Perez-Amador, M.A.; Kollist, H.; et al. Arabidopsis PYR/PYL/RCAR receptors play a major role in quantitative regulation of stomatal aperture and transcriptional response to abscisic acid. Plant Cell 2012, 24, 2483-2496. [CrossRef]

36. Miao, C.B.; Xiao, L.H.; Hua, K.; Zou, C.; Zhao, Y.; Bressan, R.A.; Zhu, J.K. Mutations in a subfamily of abscisic acid receptor genes promote rice growth and productivity. Proc. Natl. Acad. Sci. USA 2018, 115, 6058-6063. [CrossRef]

37. Zhao, Y.; Zhang, Z.J.; Gao, J.H.; Wang, P.C.; Hu, T.; Wang, Z.G.; Hou, Y.J.; Wan, Y.Z.; Liu, W.S.; Xie, S.J.; et al. Arabidopsis duodecuple mutant of PYL ABA receptors Reveals PYL repression of ABA-independent SnRK2 activity. Cell Rep. 2018, 23, 3340. [CrossRef]

38. Umezawa, T.; Nakashima, K.; Miyakawa, T.; Kuromori, T.; Tanokura, M.; Shinozaki, K.; Yamaguchi-Shinozaki, K. Molecular basis of the core regulatory network in ABA responses: Sensing, signaling and transport. Plant Cell Physiol. 2010, 51, 1821-1839. [CrossRef]

39. Leung, J.; Merlot, S.; Giraudat, J. The Arabidopsis ABSCISE ACID-INSENSITIVE2 (ABI2) and ABI1 genes encode homologous protein phosphatase 2C involved in abscisic acid signal transduction. Plant Cell 1997, 9, 759-771.

40. Nishimura, N.; Yoshida, T.; Kitahata, N.; Asami, T.; Shinozaki, K.; Hirayama, T. ABA-Hypersensitive Germination1 encodes a protein phosphatase 2C, an essential component of abscisic acid signaling in Arabidopsis seed. Plant J. 2007, 50, 935-949. [CrossRef]

41. Robert, N.; Merlot, S.; N'guyen, V.; Boisson-Dernier, A.; Schroeder, J.I. A hypermorphic mutation in the protein phosphatase 2C HAB1 strongly affects ABA signaling in Arabidopsis. FEBS Lett. 2006, 580, 4691-4696. [CrossRef]

42. Boudsocq, M.; Barbier-Brygoo, H.; Lauriere, C. Identification of nine sucrose nonfermenting 1-related protein kinases 2 activated by hyperosmotic and saline stresses in Arabidopsis thaliana. J. Biol. Chem. 2004, 279, 41758-41766. [CrossRef]

43. Dejonghe, W.; Okamoto, M.; Cutler, S.R. Small molecule probes of ABA biosynthesis and signaling. Plant Cell Physiol. 2018, 59, 1490-1499. [CrossRef]

44. Hewage, K.A.H.; Yang, J.F.; Wang, D.; Hao, G.F.; Yang, G.F.; Zhu, J.K. Chemical manipulation of abscisic acid signaling: A new approach to abiotic and biotic stress management in agriculture. Adv. Sci. 2020, 7, 2001265. [CrossRef]

45. Zhao, F.Y.; Cai, F.X.; Gao, H.J.; Zhang, S.Y.; Wang, K.; Liu, T.; Wang, X. ABA plays essential roles in regulating root growth by interacting with auxin and MAPK signaling pathways and cell-cycle machinery in rice seedlings. Plant Growth Regul. 2014, 75, 535-547. [CrossRef]

46. Takatsuka, H.; Umeda, M. Hormonal control of cell division and elongation along differentiation trajectories in roots. J. Exp. Bot. 2014, 65, 2633-2643. [CrossRef]

47. Takatsuka, H.; Umeda, M. ABA inhibits root cell elongation through repressing the cytokinin signaling. Plant Signal. Behav. 2019, 14, e1578632. [CrossRef] [PubMed]

48. Huang, X.; Zhang, X.; Gong, Z.; Yang, S.; Shi, Y. ABI4 represses the expression of type-A ARRs to inhibit seed germination in Arabidopsis. Plant J. 2017, 89, 354-365. [CrossRef]

49. Scofield, S.; Dewitte, W.; Nieuwland, J.; Murray, J.A.H. The Arabidopsis homeobox gene SHOOT MERISTEMLESS has cellular and meristem-organisational roles with differential requirements for cytokinin and CYCD3 activity. Plant J. 2013, 75, 53-66. [CrossRef]

50. Hemerly, A.S.; Ferreira, P.; Engler, J.D.A.; Montagu, M.V.; Engler, G.; Inzé, D. cdca2 expression in Arabidopsis is linked with competence for cell division. Plant Cell 1993, 5, 1711-1723. [PubMed]

51. Burssens, S.; Engler, J.D.A.; Beeckman, T.; Richard, C.; Shaul, O.; Ferreira, P.; Montagu, M.V.; Inzé, D. Developmental expression of the Arabidopsis thaliana CycA2;1 gene. Planta 2000, 211, 623-631. [CrossRef] [PubMed]

52. Lipavská, H.; Mašková, P.; Vojvodová, P. Regulatory dephosphorylation of $C D K$ at $\mathrm{G}_{2} / \mathrm{M}$ in plants: Yeast mitotic phosphatase cdc25 induces cytokinin-like effects in transgenic tobacco morphogenesis. Ann. Bot. 2011, 107, 1071-1086. [CrossRef]

53. Melaragno, J.E.; Mehrotra, B.; Coleman, A.W. Relationship between endopolyploidy and cell size in epidermal tissue of Arabidopsis. Plant Cell 1993, 5, 1661-1668. [CrossRef]

54. Shimotohno, A.; Aki, S.S.; Takahashi, N.; Umeda, M. Regulation of the plant cell cycle in response to hormones and the environment. Annu. Rev. Plant Biol. 2021, 72, 273-296. [CrossRef]

55. Milborrow, B.V. The chemistry and physiology of abscisic acid. Ann. Rev. Plant Physiol. 1974, 25, 259-307. [CrossRef]

56. Pierik, R.; Tholen, D.; Poorter, H.; Visser, E.J.W.; and Voesenek, L.A.C.J. The Janus face of ethylene: Growth inhibition and stimulation. Trends Plant Sci. 2006, 11, 176-183. [CrossRef] [PubMed]

57. Han, H.B.; Adamowski, M.; Qi, L.L.; Alotaibi, S.S.; Friml, J. PIN-mediated polar auxin transport regulations in plant tropic responses. New Phytol. 2021, 232, 510-522. [CrossRef] [PubMed]

58. Nguyen, H.N.; Lai, N.; Kisiala, A.B.; Emery, R.J.N. Isopentenyltransferases as master regulators of crop performance: Their function, manipulation, and genetic potential for stress adaptation and yield improvement. Plant Biotechnol. J. 2021, 19, 1297-1313. [CrossRef] [PubMed]

59. Benschop, J.J.; Millenaar, F.F.; Smeets, M.E.; van Zanten, M.; Voesenek, L.A.C.J.; Peeters, A.J.M. Abscisic acid antagonizes ethylene-induced hyponastic growth in Arabidopsis. Plant Physiol. 2007, 143, 1013-1023. [CrossRef] [PubMed] 
60. Barrero, J.M.; Piqueras, P.; González-Guzmán, M.; Serrano, R.; Rodríguez, P.L.; Ponce, M.R.; Micol, J.L. A mutational analysis of the ABA1 gene of Arabidopsis thaliana highlights the involvement of ABA in vegetative development. J. Exp. Bot. 2005, 56, 2071-2083. [CrossRef]

61. Zhang, H.; Han, W.; De Smet, I.; Talboys, P.; Loya, R.; Hassan, A.; Rong, H.; Jurgens, G.; Paul Knox, J.; Wang, M.H. ABA promotes quiescence of the quiescent centre and suppresses stem cell differentiation in the Arabidopsis primary root meristem. Plant $J$. 2010, 64, 764-774. [CrossRef]

62. Barrero, J.M.; Rodriguez, P.L.; Quesada, V.; Alabadi, D.; Blazquez, M.A.; Boutin, J.P.; Marion-Poll, A.; Ponce, M.R.; Micol, J.L. The ABA1 gene and carotenoid biosynthesis are required for late skotomorphogenic growth in Arabidopsis thaliana. Plant Cell Environ. 2008, 31, 227-234. [CrossRef]

63. Lake, J.A.; Woodward, F.I.; Quick, W.P. Long-distance $\mathrm{CO}_{2}$ signalling in plants. J. Exp. Bot. 2002, 53, 183-193. [CrossRef] [PubMed]

64. Lake, J.A.; Woodward, F.I. Response of stomatal numbers to $\mathrm{CO}_{2}$ and humidity: Control by transpiration rate and abscisic acid. New Phytol. 2008, 179, 397-404. [CrossRef]

65. Frey, A.; Effroy, D.; Lefebvre, V.; Seo, M.; Perreau, F.; Berger, A.; Sechet, J.; To, A.; North, H.M.; Marion-Poll, A. Epoxycarotenoid cleavage by NCED5 fine-tunes ABA accumulation and affects seed dormancy and drought tolerance with other NCED family members. Plant J. 2012, 70, 501-512. [CrossRef]

66. Chater, C.; Peng, K.; Movahedi, M.; Dunn, J.A.; Walker, H.J.; Liang, Y.K.; McLachlan, D.H.; Casson, S.; Isner, J.C.; Wilson, I.; et al. Elevated $\mathrm{CO}_{2}$-induced responses in stomata require ABA and ABA signaling. Curr. Biol. 2015, 25, 2709-2716. [CrossRef] [PubMed]

67. Yoshida, T.; Obata, T.; Feil, R.; Lunn, J.E.; Fujita, Y.; Yamaguchi-Shinozaki, K.; Fernie, A.R. The role of abscisic acid signaling in maintaining the metabolic balance required for Arabidopsis growth under nonstress conditions. Plant Cell 2019, 31, 84-105. [CrossRef]

68. Cheng, W.-H.; Endo, A.; Zhou, L.; Penney, J.; Chen, H.-C.; Arroyo, A.; Leon, P.; Nambara, E.; Asami, T.; Seo, M.; et al. A unique short-chain dehydrogenase/reductase in Arabidopsis glucose signaling and abscisic acid biosynthesis and functions. Plant Cell 2002, 14, 2723-2743. [CrossRef]

69. LeNoble, M.E.; Spollen, W.G.; Sharp, R.E. Maintenance of shoot growth by endogenous ABA: Genetic assessment of the involvement of ethylene suppression. J. Exp. Bot. 2004, 55, 237-245. [CrossRef]

70. Leon, P.; Sheen, J. Sugar and hormone connections. Trends Plant Sci. 2003, 8, 110-116. [CrossRef]

71. L'Haridon, F.; Besson-Bard, A.; Binda, M.; Serrano, M.; Abou-Mansour, E.; Balet, F.; Schoonbeek, H.J.; Hess, S.; Mir, R.; Léon, J.; et al. A permeable cuticle is associated with the release of reactive oxygen species and induction of innate immunity. PLoS Pathog. 2011, 7, e1002148. [CrossRef] [PubMed]

72. Tanaka, Y.; Nose, T.; Jikumaru, Y.; Kamiya, Y. ABA inhibits entry into stomatal-lineage development in Arabidopsis leaves. Plant J. 2013, 74, 448-457. [CrossRef]

73. Ramachandran, P.; Wang, G.; Augstein, F.; de Vries, J.; Carlsbecker, A. Continuous root xylem formation and vascular acclimation to water deficit involves endodermal ABA signalling via miR165. Development 2018, 145, dev159202. [CrossRef]

74. Bloch, D.; Puli, M.R.; Mosquna, A.; Yalovsky, S. Abiotic stress modulates root patterning via ABA-regulated microRNA expression in the endodermis initials. Development 2019, 146, dev177097. [CrossRef] [PubMed]

75. Lee, L.R.; Bergmann, D.C. The plant stomatal lineage at a glance. J. Cell Sci. 2019, 132, jcs228551. [CrossRef] [PubMed]

76. Barberon, M.; Vermeer, J.; De Bellis, D.; Wang, P.; Naseer, S.; Andersen, T.; Humbel, B.; Nawrath, C.; Takano, J.; Salt, D.; et al. Adaptation of root function by nutrient-induced plasticity of endodermal differentiation. Cell 2016, 164, 447-459. [CrossRef]

77. Léon-Kloosterziel, K.M.; Gil, M.A.; Ruijs, G.J.; Jacobsen, S.E.; Olszewski, N.E.; Schwartz, S.H.; Zeevaart, J.A.; Koornneef, M. Isolation and characterization of abscisic acid-deficient Arabidopsis mutants at two new loci. Plant J. 1996, 10, 655-661. [CrossRef]

78. Cui, F.; Brosché, M.; Lehtonen, M.T.; Amiryousefi, A.; Xu, E.; Punkkinen, M.; Valkonen, J.P.; Fujii, H.; Overmyer, K. Dissecting abscisic acid signaling pathways involved in cuticle formation. Mol. Plant 2016, 9, 926-938. [CrossRef]

79. Seo, M.; Peeters, A.J.M.; Koiwai, H.; Oritani, T.; Marion-Poll, A.; Zeevaart, J.A.D.; Koornneef, M.; Kamiya, Y.; Koshiba, T. The Arabidopsis aldehyde oxidase 3 (AAO3) gene product catalyzes the final step in abscisic acid biosynthesis in leaves. Proc. Natl. Acad. Sci USA 2000, 97, 12908-12913. [CrossRef]

80. Rubio, S.; Rodrigues, A.; Saez, A.M.B.; Galle, A.; Kim, T.H.; Santiago, J.; Flexas, J.; Schroeder, J.I.; Rodriguez, P.L. Triple loss of function of protein phosphatases type $2 \mathrm{C}$ leads to partial constitutive response to endogenous abscisic acid. Plant Physiol. 2009, 150, 1345-1355. [CrossRef]

81. Liu, C.; Rao, X.; Li, L.; Dixon, R.A. Abscisic acid regulates secondary cell-wall formation and lignin deposition in Arabidopsis thaliana through phosphorylation of NST1. Proc. Natl. Acad. Sci. USA 2021, 118, e2010911118. [CrossRef] [PubMed]

82. Shkolnik-Inbar, D.; Bar-Zvi, D. ABI4 mediates abscisic acid and cytokinin inhibition of lateral root formation by reducing polar auxin transport in Arabidopsis. Plant Cell 2010, 22, 3560-3573. [CrossRef]

83. Allen, J.; Guo, K.; Zhang, D.; Ince, M.; Jammes, F. ABA-glucose ester hydrolyzing enzyme ATBG1 and PHYB antagonistically regulate stomatal development. PLoS ONE 2019, 14, e0218605. [CrossRef]

84. Jones, H.G.; Sharp, C.S.; Higgs, K.H. Growth and water relations of wilty mutants of tomato (Lycopersicon esculentum Mill.). J. Exp. Bot. 1987, 38, 1848-1856. [CrossRef]

85. Sharp, R.E.; LeNoble, M.E.; Else, M.A.; Thorne, E.T.; and Gherardi, F. Endogenous ABA maintains shoot growth in tomato independently of effects on plant water balance: Evidence for an interaction with ethylene. J. Exp. Bot. 2000, 51, 1575-1584. [CrossRef]

86. Nitsch, L.; Kohen, W.; Oplaat, C.; Charnikhova, T.; Cristescu, S.; Michieli, P.; Wolters-Arts, M.; Bouwmeester, H.; Mariani, C.; Vriezen, W.H.; et al. ABA-deficiency results in reduced plant and fruit size in tomato. J. Plant Physiol. 2012, 169, 878-883. [CrossRef] 
87. Humplik, J.F.; Bergougnoux, V.; Jandova, M.; Simura, J.; Pencik, A.; Tomanec, O.; Rolcik, J.; Novak, O.; Fellner, M. Endogenous abscisic acid promotes hypocotyl growth and affects endoreduplication during dark-Induced growth in tomato (Solanum lycopersicum L.). PLoS ONE 2015, 10, 0117793. [CrossRef]

88. Tal, M. Abnormal stomatal behavior in wilty mutants of tomato. Plant Physiol. 1966, 41, 1387-1391. [CrossRef]

89. Gazzarrini, S.; McCourt, P. Genetic interactions between ABA, ethylene and sugar signaling pathways. Curr. Opin. Plant Biol. 2001, 4, 387-391. [CrossRef]

90. Casson, S.A.; Hetherington, A.M. GSK3-like kinases integrate brassinosteroid signaling and stomatal development. Sci. Signal. 2012, 5, pe30. [CrossRef] [PubMed]

91. Gong, Y.; Alassimone, J.; Varnau, R.; Sharmam, N.; Cheungm, L.S.; Bergmann, D.C. Tuning self-renewal in the Arabidopsis stomatal lineage by hormone and nutrient regulation of asymmetric cell division. eLife 2021, 10, e63335. [CrossRef] [PubMed]

92. Poor, P.; Borbely, P.; Czekus, Z.; Takacs, Z.; Ordog, A.; Popovic, B.; Tari, I. Comparison of changes in water status and photosynthetic parameters in wild type and abscisic acid-deficient sitiens mutant of tomato (Solanum lycopersicum cv. Rheinlands Ruhm) exposed to sublethal and lethal salt stress. J. Plant Physiol. 2019, 232, 130-140. [CrossRef]

93. Innes, S.N.; Solhaug, K.A.; Torre, S.; Dodd, I.C. Different abscisic acid-deficient mutants show unique morphological and hydraulic responses to high air humidity. Physiol. Plant. 2021, 172, 1795-1807. [CrossRef]

94. McAdam, S.A.M.; Brodribb, T.J.; Ross, J.J. Shoot-derived abscisic acid promotes root growth. Plant Cell Environ. 2016, 39, 652-659. [CrossRef] [PubMed]

95. Nagel, O.W.; Konings, H.; Lambers, H. Growth rate, plant development and water relations of the ABA-deficient tomato mutant sitiens. Physiol Plant. 1994, 92, 102-108. [CrossRef]

96. Curvers, K.; Seifi, H.; Mouille, G.; de Rycke, R.; Asselbergh, B.; Van Hecke, A.; Vanderschaeghe, D.; Höfte, H.; Callewaert, N.; Van Breusegem, F.; et al. Abscisic acid deficiency causes changes in cuticle permeability and pectin composition that influence tomato resistance to Botrytis cinerea. Plant Physiol. 2010, 154, 847-860. [CrossRef]

97. Martin, L.B.B.; Romero, P.; Fich, E.A.; Domozych, D.S.; Rose, J.K.C. Cuticle biosynthesis in tomato leaves is developmentally regulated by abscisic acid. Plant Physiol. 2017, 174, 1384-1398. [CrossRef]

98. Spollen, W.G.; LeNoble, M.E.; Samuels, T.D.; Bernstein, N.; Sharp, R.E. Abscisic acid accumulation maintains maize primary root elongation at low water potentials by restricting ethylene production. Plant Physiol. 2000, 122, 967-976. [CrossRef]

99. Saika, H.; Okamoto, M.; Miyoshi, K.; Kushiro, T.; Shinoda, S.; Jikumaru, Y.; Fujimoto, M.; Arikawa, T.; Takahashi, H.; Ando, M.; et al. Ethylene promotes submergence-induced expression of OsABA8ox1, a gene that encodes ABA 8'-hydroxylase in rice. Plant Cell Physiol. 2007, 48, 287-298. [CrossRef] [PubMed]

100. van Zanten, M.; Pons, T.L.; Janssen, J.A.M.; Voesenek, L.A.C.J.; Peeters, A.J.M. On the relevance and control of leaf angle. CRC Crit. Rev. Plant Sci. 2010, 29, 300-316. [CrossRef]

101. Benschop, J.J.; Jackson, M.B.; Guhl, K.; Vreeburg, R.A.M.; Croker, S.J.; Peeters, A.J.M.; Voesenek, L.A.C.J. Contrasting interactions between ethylene and abscisic acid in Rumex species differing in submergence tolerance. Plant J. 2005, 44, 756-768. [CrossRef] [PubMed]

102. Chen, X.; Pierik, R.; Peeters, A.J.M.; Poorter, H.; Visser, E.J.W.; Huber, H.; de Kroon, H. Endogenous abscisic acid as a key switch for natural variation in flooding-induced shoot elongation. Plant Physiol. 2010, 154, 969-977. [CrossRef]

103. Toriyama, T.; Shinozawa, A.; Yasumura, Y.; Saruhashi, M.; Hiraide, M.; Ito, S.; Matsuura, H.; Kuwata, K.; Yoshida, M.; Baba, T.; et al. Sensor histidine kinases mediate ABA and osmostress signaling in the moss Physcomitrium patens. Curr. Biol. 2021, 32, 1-12. [CrossRef]

104. Emenecker, R.J.; Strader, L.C. Auxin-abscisic acid interactions in plant growth and development. Biomolecules 2020, $10,281$. [CrossRef]

105. Zhao, Y.; Xing, L.; Wang, X.; Hou, Y.J.; Gao, J.; Wang, P.; Duan, C.G.; Zhu, X.; Zhu, J.K. The ABA receptor PYL8 promotes lateral root growth by enhancing MYB77-dependent transcription of auxin-responsive genes. Sci. Signal. 2014, 7, ra53. [CrossRef] [PubMed]

106. Zheng, Z.F.; Xu, X.P.; Crosley, R.A.; Greenwalt, S.A.; Sun, Y.J.; Blakeslee, B.; Wang, L.Z.; Ni, W.T.; Sopko, M.S.; Yao, C.L.; et al. The protein kinase SnRK2.6 mediates the regulation of sucrose metabolism and plant growth in Arabidopsis. Plant Physiol. 2010, 153, 99-113. [CrossRef]

107. Li, X.; Chen, L.; Forde, B.G.; Davies, W.J. The biphasic root growth response to abscisic acid in Arabidopsis involves interaction with ethylene and auxin signalling pathways. Front. Plant Sci. 2017, 8, 1493. [CrossRef] [PubMed]

108. Gendreau, E.; Traas, J.; Desnos, T.; Grandjean, O.; Caboche, M.; Hofte, H. Cellular basis of hypocotyl growth in Arabidopsis thaliana. Plant Physiol. 1997, 114, 295-305. [CrossRef] [PubMed]

109. Wang, H.; Qi, Q.; Schorr, P.; Cutler, A.J.; Crosby, W.L.; Fowke, L.C. ICK1, a cyclin-dependent protein kinase inhibitor from Arabidopsis thaliana interacts with both Cdc2a and CycD3, and Its expression Is induced by abscisic acid. Plant J. 1998, 15, 501-510. [CrossRef]

110. Bai, Q.; Huang, Y.; Shen, Y. The physiological and molecular mechanism of abscisic acid in regulation of freshy fruit ripening. Front. Plant Sci. 2021, 11, 619953. [CrossRef] [PubMed]

111. Kou, X.H.; Yang, S.; Chai, L.P.; Wu, C.E.; Zhou, J.Q.; Liu, Y.F.; Xue, Z.H. Abscisic acid and fruit ripening: Multifaceted analysis of the effect of abscisic acid on fleshy fruit ripening. Sci. Hortic. 2021, 281, 109999. [CrossRef] 
112. Zhang, Y.S.; Li, Q.; Jiang, L.; Kai, W.B.; Liang, B.; Wang, J.; Du, Y.W.; Zhai, X.W.; Wang, J.L.; Zhang, Y.Q. Suppressing type 2C protein phosphatases alters fruit ripening and the stress response in tomato. Plant Cell Physiol. 2018, 59, 142-154. [CrossRef]

113. Kai, W.B.; Wang, J.; Liang, B.; Fu, Y.; Zheng, Y.; Zhang, W.B.; Li, Q.; Leng, P. PYL9 is involved in the regulation of ABA signaling during tomato fruit ripening. J. Exp. Bot. 2019, 70, 6305-6319. [CrossRef] [PubMed]

114. Zhang, M.; Yuan, B.; Leng, P. The role of ABA in triggering ethylene biosynthesis and ripening of tomato fruit. J. Exp. Bot. 2009, 60, 1579-1588. [CrossRef] [PubMed]

115. Fujita, Y.; Fujita, M.; Shinozaki, K.; Yamaguchi-Shinozaki, K. ABA-mediated transcriptional regulation in response to osmotic stress in plants. J. Plant Res. 2011, 124, 509-525. [CrossRef]

116. Yamburenko, M.V.; Zubo, Y.O.; Borner, T. Abscisic acid affects transcription of chloroplast genes via protein phosphatase 2Cdependent activation of nuclear genes: Repression by guanosine-3-5-bisdiphosphate and activation by sigma factor 5. Plant J. 2015, 82, 1030-1041. [CrossRef]

117. Gibson, S.I. Sugar and phytohormone response pathways: Navigating a signaling network. J. Exp. Bot. 2004, 55, 253-264. [CrossRef]

118. Ma, Q.J.; Sun, M.H.; Lu, J.; Liu, Y.J.; Hu, D.G.; Hao, Y.J. Transcription factor AREB2 is involved in soluble sugar accumulation by activating sugar transporter and amylase genes. Plant Physiol. 2017, 174, 2348-2362. [CrossRef]

119. Yeats, T.H.; Rose, J.K.C. The formation and function of plant cuticles. Plant Physiol. 2013, 163, 5-20. [CrossRef]

120. Nawrath, C.; Schreiber, L.; Franke, R.B.; Geldner, N.; Reina-Pinto, J.J.; Kunst, L. Apoplastic diffusion barriers in Arabidopsis. Arabidopsis Book 2013, 11, e0167. [CrossRef]

121. Asad, M.A.U.; Zakari, S.A.; Zhao, Q.; Zhou, L.; Ye, Y.; Cheng, F. Abiotic Stresses Intervene with ABA Signaling to Induce Destructive Metabolic Pathways Leading to Death: Premature Leaf Senescence in Plants. Int. J. Mol. Sci. 2019, 20, 256. [CrossRef] [PubMed]

122. Forlani, S.; Masiero, S.; Mizzotti, C. Fruit ripening: The role of hormones, cell wall modifications, and their relationship with pathogens. Journal of Experimental Botany 2019, 70, 2993-3006. [CrossRef]

123. Salaün, C.; Lepiniec, L.; Dubreucq, B. Genetic and Molecular Control of Somatic Embryogenesis. Plants 2021, 10, 1467. [CrossRef]

124. Assmann, S.M.; Jegla, T. Guard cell sensory systems: Recent insights on stomatal responses to light, abscisic acid, and $\mathrm{CO}_{2}$. $\mathrm{Curr}$ Opin. Plant Biol. 2016, 33, 157-167. [CrossRef]

125. Bradford, K.J.; Sharkey, T.D.; Farquhar, G.D. Gas exchange, stomatal behavior, and delta ${ }^{13} \mathrm{C}$ values of the flacca tomato mutant in relation to abscisic acid. Plant Physiol. 1983, 72, 245-250. [CrossRef] [PubMed]

126. Qi, X.; Torii, K.U. Hormonal and environmental signals guiding stomatal development. BMC Biol. 2018, 16, 21. [CrossRef]

127. Chater, C.C.; Oliver, J.; Cassonm, S.; Graym, J.E. Putting the brakes on: Abscisic acid as a central environmental regulator of stomatal development. New Phytol. 2014, 202, 376-391. [CrossRef] [PubMed]

128. Wei, H.; Jing, Y.; Zhang, L.; Kong, D. Phytohormones and their crosstalk in regulating stomatal development and patterning. J. Exp. Bot. 2021, 72, 2356-2370. [CrossRef]

129. Saibo, N.J.; Vriezen, W.H.; Beemster, G.T.; Van Der Straeten, D. Growth and stomata development of Arabidopsis hypocotyls are controlled by gibberellins and modulated by ethylene and auxins. Plant J. 2003, 33, 989-1000. [CrossRef] [PubMed]

130. Gudesblat, G.; Schneider-Pizoń, J.; Betti, C.; Mayerhofer, J.; Vanhoutte, I.; van Dongen, W.; Boeren, S.; Zhiponova, M.; de Vries, S.; Jonak, C.; et al. SPEECHLESS integrates brassinosteroid and stomata signalling pathways. Nat. Cell Biol. 2012, 14, 548-554. [CrossRef]

131. Kim, T.W.; Michniewicz, M.; Bergmann, D.C.; Wang, Z.Y. Brassinosteroid regulates stomatal development by GSK3-mediated inhibition of a MAPK pathway. Nature 2012, 482, 419-422. [CrossRef]

132. Le, J.; Liu, X.G.; Yang, K.Z.; Chen, X.L.; Zou, J.J.; Wang, H.Z.; Wang, M.; Vanneste, S.; Morita, M.; Tasaka, M.; et al. Auxin transport and activity regulate stomatal patterning and development. Nat. Commun. 2014, 5, 3090. [CrossRef]

133. Zhang, J.Y.; Je, S.B.; Li, L.; Yang, H.Q. Auxin inhibits stomatal development through MONOPTEROS repression of a mobile peptide gene STOMAGEN in mesophyll. Proc. Natl. Acad. Sci. USA 2014, 111, E3015-E3023. [CrossRef]

134. Balcerowicz, M.; Ranjan, A.; Rupprecht, L.; Fiene, G.; Hoecker, U. Auxin represses stomatal development in dark-grown seedlings via Aux/IAA proteins. Development 2014, 141, 3165-3176. [CrossRef]

135. Vatén, A.; Soyars, C.L.; Tarr, P.T.; Nimchuk, Z.L.; Bergmann, D.C. Modulation of asymmetric division diversity through cytokinin and SPEECHLESS regulatory interactions in the Arabidopsis stomatal lineage. Dev. Cell 2018, 47, 53-66.e5. [CrossRef] [PubMed]

136. Li, K.; Yang, F.; Zhang, G.; Song, S.; Li, Y.; Ren, D.; Miao, Y.; Song, C.P. AIK1, a mitogen-activated protein kinase, modulates abscisic acid responses through the MKK5-MPK6 kinase cascade. Plant Physiol. 2017, 173, 1391-1408. [CrossRef] [PubMed]

137. Kunst, L. New insights into biosynthesis of cuticular wax. FASEB J. 2015, 29, 366.3. [CrossRef]

138. Kosma, D.K.; Bourdenx, B.; Bernard, A.; Parsons, E.P.; Lü, S.; Joubès, J.; Jenks, M.A. The impact of water deficiency on leaf cuticle lipids of Arabidopsis. Plant Physiol. 2009, 151, 1918-1929. [CrossRef] [PubMed]

139. Seo, P.J.; Lee, S.B.; Suh, M.C.; Park, M.J.; Go, Y.S.; Park, C.M. The MYB96 transcription factor regulates cuticular wax biosynthesis under drought conditions in Arabidopsis. Plant Cell 2011, 23, 1138-1152. [CrossRef]

140. Lee, S.B.; Kim, H.U.; Suh, M.C. MYB94 and MYB96 additively activate cuticular wax biosynthesis in Arabidopsis. Plant Cell Physiol. 2016, 57, 2300-2311. [CrossRef]

141. Zhao, Y.; Chan, Z.; Gao, J.; Xing, L.; Cao, M.; Yu, C.; Hu, Y.; You, J.; Shi, H.; Zhu, Y.; et al. ABA receptor PYL9 promotes drought resistance and leaf senescence. Proc. Natl. Acad. Sci. USA 2016, 113, 1949-1954. [CrossRef] 
142. Samuels, L.; Kunst, L.; Jetter, R. Sealing plant surfaces: Cuticular wax formation by epidermal cells. Annu. Rev. Plant Biol. 2008, 59, 683-707. [CrossRef]

143. Lewandowska, M.; Keyl, A.; Feussner, I. Wax biosynthesis in response to danger: Its regulation upon abiotic and biotic stress. New Phytol. 2020, 227, 698-713. [CrossRef]

144. Wang, Z.Y.; Xiong, L.; Li, W.; Zhu, J.K.; Zhum, J. The plant cuticle is required for osmotic stress regulation of abscisic acid biosynthesis and osmotic stress tolerance in Arabidopsis. Plant Cell 2011, 23, 1971-1984. [CrossRef]

145. Ramachandran, P.; Augstein, F.; Nguyen, V.; Carlsbeckerm, A. Coping with water limitation: Hormones that modify plant root xylem development. Front. Plant Sci. 2020, 11, 570. [CrossRef]

146. Carlsbecker, A.; Lee, J.-Y.; Roberts, C.J.; Dettmer, J.; Lehesranta, S.; Zhou, J.; Lindgren, O.; Moreno-Risueno, M.A.; Vatén, A.; Thitamadee, S.; et al. Cell signalling by microRNA165/6 directs gene dose-dependent root cell fate. Nature 2010, 465, 316-321. [CrossRef]

147. Miyashima, S.; Koi, S.; Hashimoto, T.; Nakajima, K. Non-cell-autonomous microRNA165 acts in a dose-dependent manner to regulate multiple differentiation status in the Arabidopsis root. Development 2011, 138, 2303-2313. [CrossRef]

148. Awad, H.; Barigah, T.; Badel, E.; Cochard, H.; Herbette, S. Poplar vulnerability to xylem cavitation acclimates to drier soil conditions. Physiol. Plant 2010, 139, 280-288. [CrossRef]

149. Arend, M.; Fromm, J. Seasonal change in the drought response of wood cell development in poplar. Tree Physiol. 2007, 27, 985-992. [CrossRef]

150. Ryu, J.; Hwang, B.G.; Kim, Y.X.; Lee, S.J. Direct observation of local xylem embolisms induced by soil drying in intact Zea mays leaves. J. Exp. Bot. 2016, 67, 2617-2626. [CrossRef] [PubMed]

151. Prince, S.J.; Murphy, M.; Mutava, R.N.; Durnell, L.A.; Valliyodan, B.; Shannon, J.G.; Nguyen, H.T. Root xylem plasticity to improve water use and yield in water-stressed soybean. J. Exp. Bot. 2017, 68, 2027-2036. [CrossRef] [PubMed]

152. Ursache, R.; Miyashimam, S.; Chen, Q.; Vatén, A.; Nakajima, K.; Carlsbecker, A.; Zhao, Y.; Helariuttam, Y.; Dettmerm, J. Tryptophan-dependent auxin biosynthesis is required for HD-ZIP III-mediated xylem patterning. Development 2014, 141, 1250-1259. [CrossRef] [PubMed]

153. Müller, C.J.; Valdés, A.E.; Wang, G.; Ramachandran, P.; Beste, L.; Uddenberg, D.; Carlsbecker, A. PHABULOSA mediates an auxin signaling loop to regulate vascular patterning in Arabidopsis. Plant Physiol. 2016, 170, 956-970. [CrossRef]

154. Cottle, W.; Kolattukudy, P.E. Abscisic acid stimulation of suberization: Induction of enzymes and deposition of polymeric components and associated waxes in tissue cultures of potato tuber. Plant Physiol. 1982, 70, 775-780. [CrossRef]

155. Boher, P.; Serra, O.; Soler, M.; Molinas, M.; Figueras, M. The potato suberin feruloyl transferase FHT which accumulates in the phellogen is induced by wounding and regulated by abscisic and salicylic acids. J. Exp. Bot. 2013, 64, 3225-3236. [CrossRef]

156. Kosma, D.; Murmu, J.; Razeq, F.; Santos, P.; Bourgault, R.; Molina, I.; Rowland, O. At MYB 41 activates ectopic suberin synthesis and assembly in multiple plant species and cell types. Plant J. 2014, 80, 216-229. [CrossRef]

157. Yadav, V.; Molina, I.; Ranathunge, K.; Castillo, I.Q.; Rothstein, S.J.; Reed, J.W. ABCG transporters are required for suberin and pollen wall extracellular barriers in Arabidopsis. Plant Cell 2014, 26, 3569-3588. [CrossRef]

158. Verdaguer, R.; Soler, M.; Serra, O.; Garrote, A.; Fernandez, S.; Company-Arumi, D.; Antico, E.; Molinas, M.; Figueras, M. Silencing of the potato StNAC103 gene enhances the accumulation of suberin polyester and associated wax in tuber skin. J. Exp. Bot. 2016, 67, 5415-5427. [CrossRef]

159. Shukla, V.; Han, J.P.; Cléard, F.; Lefebvre-Legendre, L.; Gully, K.; Flis, P.; Berhin, A.; Andersen, T.G.; Salt, D.E.; Nawrath, C.; et al. Suberin plasticity to developmental and exogenous cues is regulated by a set of MYB transcription factors. Proc. Natl. Acad. Sci. USA 2021, 118, e2101730118. [CrossRef]

160. Wei, X.; Mao, L.; Lu, W.; Wei, X.; Han, X.; Guan, W.; Yang, Y.; Zha, M.; Xu, C.; Luo, Z. Three transcription activators of ABA signaling positively regulate suberin monomer synthesis by activating cytochrome P450 CYP86A1 in kiwifruit. Front. Plant Sci. 2020, 10, 1650. [CrossRef] [PubMed]

161. Cohen, H.; Fedyuk, V.; Wang, C.; Wu, S.; Aharoni, A. SUBERMAN regulates developmental suberization of the Arabidopsis root endodermis. Plant J. 2020, 102, 431-447. [CrossRef] [PubMed]

162. Salas-González, I.; Reyt, G.; Flis, P.; Custódio, V.; Gopaulchan, D.; Bakhoum, N.; Dew, T.P.; Suresh, K.; Franke, R.B.; Dangl, J.L.; et al. Coordination between microbiota and root endodermis supports plant mineral nutrient homeostasis. Science 2021, 371, eabd0695. [CrossRef] [PubMed]

163. Hussain, S.; Gomes, M.M.; Yano, K.; Nambara, E. Interactions between abscisic acid and other hormones. In Advances in Botanical Research, Abscise Acid in Plants; Seo, M., Marion-Poll, A., Eds.; Elsevier: Oxford, UK, 2019; Volume 92, pp. 255-280.

164. Dong, Z.; Yu, Y.; Li, S.; Wang, J.; Tang, S.; Huang, R. Abscisic acid antagonizes ethylene production through the ABI4-mediated transcriptional repression of ACS4 and ACS8 in Arabidopsis. Mol. Plant 2016, 9, 126-135. [CrossRef] [PubMed] 